NBER WORKING PAPER SERIES

TRADES OF THE LIVING DEAD:

STYLE DIFFERENCES, STYLE PERSISTENCE AND PERFORMANCE OF CURRENCY FUND MANAGERS

\author{
Momtchil Pojarliev \\ Richard M. Levich \\ Working Paper 14355 \\ http://www.nber.org/papers/w14355 \\ NATIONAL BUREAU OF ECONOMIC RESEARCH \\ 1050 Massachusetts Avenue \\ Cambridge, MA 02138 \\ September 2008
}

We appreciate comments from Neville Bulgin and his colleagues at Deutsche Bank on this paper. The views expressed herein are those of the author(s) and do not necessarily reflect the views of the National Bureau of Economic Research.

NBER working papers are circulated for discussion and comment purposes. They have not been peerreviewed or been subject to the review by the NBER Board of Directors that accompanies official NBER publications.

(C) 2008 by Momtchil Pojarliev and Richard M. Levich. All rights reserved. Short sections of text, not to exceed two paragraphs, may be quoted without explicit permission provided that full credit, including $\odot$ notice, is given to the source. 
Trades of the Living Dead: Style Differences, Style Persistence and Performance of Currency Fund Managers

Momtchil Pojarliev and Richard M. Levich

NBER Working Paper No. 14355

September 2008

JEL No. F31,G11,G15

\begin{abstract}
We make use of a new database on daily currency fund manager returns over a three-year period, 2005-08. This higher frequency data allows us to estimate both alpha measures of performance and beta style factors on a yearly basis, which in turn allows us to test for persistence. We find no evidence to support alpha persistence; a manager's alpha in one year is not significantly related to his alpha in the prior year. On the other hand, there is substantial evidence for style persistence; funds that rely on carry, trend or value trading or with a long/short bias toward currency volatility are likely to maintain that style in the following year. In addition, we are able to examine the performance of managers that survive through the entire sample period, versus those that drop out. We find significant differences in both the investment styles of living versus deceased funds, as well as their realized alpha performance measures. We conjecture that both style differences and ineffective market timing, rather than market conditions, have impacted performance outcomes and induced some managers to close their funds.
\end{abstract}

Momtchil Pojarliev

Hermes Investment Management Limited

Lloyds Chambers, 1 Portsoken Street

London E1 8HZ England

m.pojarliev@hermes.co.uk

Richard M. Levich

Stern School of Business

New York University

44 West 4th Street

New York, NY 10012

and NBER

RLEVICH@STERN.NYU.EDU 


\section{Trades of the Living Dead: Style Differences, Style Persistence and Performance of Currency Fund Managers}

\section{Introduction}

A large number of academic and professional studies support the notion that various types of currency trading strategies can be quite profitable. ${ }^{1}$ Knowing that currency alpha can be easily transported into a wide range of investment products, the asset management industry is naturally very interested in currency as an asset class.

However, recent performance of currency managers has been disappointing. For example, both the Parker FX index and the Barclay Currency Traders Index (BCTI), which track the performance of currency managers, have underperformed cash (risk free returns) over the three years ending March 2008 (see Table 1). ${ }^{2}$ Performance over a three-year term is an important measure as it sometimes is associated with the "average life" of an investment mandate. ${ }^{3}$

In part, these lacklustre returns may reflect the disappointing performance of various well-known currency strategies such as carry trading, trend following, and value

\footnotetext{
${ }^{1}$ Research has focused on three types of trading strategies. The carry trade or forward rate bias strategy relies on the general tendency for currencies with high interest rates to appreciate. See Froot and Thaler (1990) for a survey and Burnside, et al. (2006) for a recent study. Technical trend following strategies rely on persistent movements in spot exchange rates. See Irwin and Park (2007) and Neely, Weller and Ulrich (2007) for surveys. Value investing strategies based on mean reversion to long run PPP exchange rates offer another approach. Studies prepared at Citibank (2003) and Deutsche Bank (2007) suggest that simple value trading strategies have been profitable.

${ }^{2}$ Some alternative currency managers' indices (the CTA Equal Weighted Currency Index and the CTA Asset Weighted Currency Index prepared by the Centre for International Securities and Derivatives Markets) show a positive return over this period. Nevertheless, opinion in the currency management industry remains strong that average returns have been poor in this period.
} 
investing. Figure 1 shows the performance of three examples of these currency trading strategies for the three years between April 2005 and March 2008. The carry strategy showed essentially zero return over the first 18 months, and then exhibited a strong run up until June 2007. But carry has given back its gains since the U.S. credit crunch began in summer 2007. As expected, the spike in currency volatility (Figure 2) coincides with the underperformance of carry trades. Returns from trend following moved mostly sideways throughout the period, although trend started to perform well in 2008. The value trading strategy oscillated between 100 and 110 but closed the period as the worst performing strategy of the three with a slightly negative return. This may not be a surprise given the climb in the spot EUR/USD rate towards 1.60, presumably further away from its "fair" value.

In earlier research, Pojarliev and Levich (PL, 2008) show that a significant part of the variation of the returns of professional currency managers can be explained by these three trading strategies and an indicator of currency volatility. PL redefine the alpha in currency management as only that portion of the excess returns which can not be explained by these four factors. In this paper, we take a closer look at the returns of professional currency managers by estimating their alpha performance measures and style betas over successive annual intervals. We are interested in the following questions: First, is past performance any indication for future performance (are alphas persistent)? Second, are investment styles (beta exposure) persistent? Third, what differences in performance are there between funds that survive throughout the sample period and those that do not? And finally, what explains difference in performance between funds that survive and those that do not?

\footnotetext{
${ }^{3}$ Recently, Gross (2005) suggests that three to four years is the "average life" of investment firms, i.e. the time frame before an average client will leave if performance disappoints.
} 
To address these questions, we rely on data for 80 currency managers for three years between April 2005 and March 2008. We estimate alpha performance measures and style betas using the four factor model proposed in PL (2008). We use higher frequency, weekly return data to obtain efficient parameters estimates for annual periods. Moreover, our database includes "dead funds" which allows us to correct for backfill and survivorship bias, and examine differences between living and deceased funds.

Overall, the results are quite interesting. We find no alpha persistence. Past performance by an individual manager seems to offer no indication for his future performance. However, we detect significant style persistence indicating that managers have a tendency to stick to the same investment style (or strategy). This may be good as it raises investor confidence that managers will stick with their original or mandated strategy. But at the same time, persistence suggests that managers are less willing to exploit market timing or reallocate their positions when other strategies look more promising. Because consultants usually "penalize" managers who do not stick to the same investment style, some style persistence may be an attempt by managers to enhance credibility with investment consultants.

We also find some important differences between managers who perform well (and survive) versus managers who perform poorly (and drop out of the database). Not surprisingly, the set of funds that died over our sample achieved a significant negative alpha and an alpha significantly less than for funds that survived until the ending date. Moreover, the surviving or live funds showed greater association (in terms of R- 
squared) with the four style factors than those funds that performed poorly and eventually died. Furthermore, contrary to the presumption of the market that underperformance of the trend-following rule has been responsible for the diminishing returns of professional currency managers, we find that the strong performance of the carry strategy until the credit crunch in the summer of 2007 was devastating for many managers, who apparently were betting on liquidation of carry trades.

In the next section of the paper, we lay out our methodology for relating currency fund returns to style factors and describe the data in our study. In section 3, we report our empirical evidence on currency fund performance over the entire three-year period for indices constructed to represent various groups of managers, including those who survive through the entire data sample (the "live" funds) and those who drop out (the "dead" funds). In section 4 , we examine the empirical evidence for individual managers over the three-year period and over one-year intervals and report our results for persistence in alpha (i.e. performance) and persistence in beta (i.e. style). Conclusions and implications of our findings are in the final section. 


\section{Methodology and Data Description}

To measure the systematic components of currency returns (the betas) and isolate the portion due to skill, we follow the approach used in PL (2008) and adopt a standard factor model of the form:

$$
R_{t}=\alpha+\sum_{i} \beta_{i} F_{i, t}+\varepsilon_{t}
$$

where

$R$ is the excess return generated by the currency manager, defined as the total return $\left(R_{t}^{*}\right)$ less the periodic risk-free rate $\left(R_{F, t}\right)$

$\alpha$ is a measure of active manager skill,

$F$ is a beta factor, that requires a systematic risk premium in the market,

$\beta$ is a coefficient or factor loading that measures the sensitivity of the manager's returns to the factor, and

$\varepsilon$ is a random error term.

To implement this approach, we require data on currency manager returns and factors that proxy for types of trading strategies and exposures that currency managers would be likely to utilize. Our empirical proxies for these factors are based on data for the major currencies that make up the vast bulk of foreign exchange trading volume. ${ }^{4}$

\section{Currency Manager Returns}

In this study, we aim to estimate alphas of currency managers over annual periods. Thus, using monthly data is not an option as twelve observations are not enough to obtain robust estimates. It is challenging to obtain higher frequency data for the returns of professional currency managers as hedge fund data providers usually 
collect monthly performance data. In this study, we make use of a new database of currency managers who are part of the Deutsche Bank (DB) FXSelect platform. ${ }^{5}$ Launched in March 2005, FXSelect is an open platform, which allows clients of Deutsche Bank to allocate their funds to different currency managers. Any currency manager can apply for registration in the platform and be accepted if he satisfies the following criteria:

a) Managers must be able to provide a daily track record for at least the last 18 months verified by a third party

b) They cannot have had more than a $20 \%$ draw-down of assets under management over the last 12 months

c) Assets under management must be at least 15 million USD

d) Satisfactory criminal and regulatory searches on key individuals

While FXSelect is a new venture, the platform is presumably an attractive means for professional currency managers to enhance their visibility and grow their client base. As such, we believe that the FXSelect data offer a fair means of assessing performance in the currency management industry. ${ }^{6}$ Most importantly for this study, daily returns data on the FXSelect platform are available, thus providing us with sufficient data to conduct an analysis of 12-month periods.

\footnotetext{
${ }^{4}$ The April 2007 survey of global foreign exchange turnover conducted by the Bank for International Settlements in 2007 shows that the G10 currencies accounted for an average $90.1 \%$ of all currency turnovers.

${ }^{5}$ We are grateful to Neville Bulgin and Rashid Hoosenally from Deutsche Bank for supplying the data. More information about FXSelect can be find in the brochure "FXSelect: An Asset Allocation Solution," Deutsche Bank, Global Markets Foreign Exchange, 2006.

${ }^{6}$ Many (about 25\%) of the managers in the FXSelect database are also included in other well known hedge fund databases (CISDM and TASS). As another example for the visibility of the platform,
} 
Deutsche Bank provided daily returns data (gross of fees) for all managers who were actively trading on the platform since its exception. To correct for accounting errors and eliminate outliers, we transformed the daily returns into weekly returns by using Wednesday observations. ${ }^{7}$ Weekly data provide 52 observations for each 12-month period, which is sufficient to obtain reasonably efficient parameter estimates with a four factor model.

\section{Backfill and Survivorship biases}

Performance evaluation needs to control for the usual biases affecting databases. In particular, backfill and survivorship biases might be severe. As indicated earlier, managers were required to submit at least 18 months of performance data before being considered for the platform. As a manager could choose the time when to approach Deutsche Bank, waiting for the "best" 18 months of past performance would have been possible. To correct for backfill bias, we use returns after a manager has actually joined the platform and started trading. Also, during our sample period, many managers have joined and exited the platform due to a poor performance. We label these managers "dead" funds. Figure 3 shows the number of "dead" funds (as of April 2008), the number of "live" funds and the total number of funds from April 2005 until March 2008. Figure 3 illustrates the magnitude of the survivorship bias. While 22 funds started in the platform in April 2005, only 15 of these funds (68\%) survived until April 2008. Almost 1/3 of the funds exited the platform within three years after listing, as we show later most likely due to poor performance. This

Deutsche Bank recently launched the Mercer Currency Manager Index - a multimanager product based on managers from the FXSelect platform chosen by Mercer Investment Consulting.

${ }^{7}$ We decided to use Wednesday as fewer bank holidays fall on Wednesday. Managers were based in different locations (US, UK, Australia, Switzerland, Monaco, Spain, Sweden, Germany, Ireland and Canada). 
highlights the necessity of including the performance of dead funds in the analyses. ${ }^{8}$

We obtained data for 80 funds in total, but only 15 of these funds had a complete 3year track record.

\section{$\underline{\text { Data for Risk Factors }}$}

\section{Carry Factor}

We use the Deutsche Bank G10 Harvest Index as the proxy for the returns of a carry strategy. ${ }^{9}$ This index reflects the return of being long the 3 high-yielding currencies against being short the 3 low-yielding currencies within the G10 currency universe. The index is rebalanced quarterly. Every quarter the currencies are re-ranked according to their current 3-month Libor rate. The Bloomberg code for this factor is DBHVG10U Index.

\section{$\underline{\text { Trend Factor }}$}

As a proxy for the trend-following factor, we use the AFX Currency Management Index. ${ }^{10}$ The AFX Index is based on trading in seven currency pairs weighted by their volume of turnover in the spot market, with returns for each pair based on an equally-

\footnotetext{
${ }^{8}$ Not correcting for backfill and survivorship biases resulted in significant alpha estimates for the average manager in 2001, 2002, 2003, 2004, 2005 and 2006. The average alpha for 2007 was also estimated to be positive, but was not significantly different from zero. These results contrast strongly with the reported results after correcting for backfill and survivorship biases, where none of the annual periods average alphas was found to be significantly different from zero.

${ }^{9}$ In this paper, we were not able to use the same proxies for risk factors as in PL (2008) as the Citi indices were provided to us only on a monthly base. On the other hand, the Deutsche Bank indices are available as daily data in Bloomberg. To check the validity of using different indices for proxies of the risk factors, we redid the regressions reported in PL (2008) for the period, which overlaps with this study, using indices from Deutsche Bank. There was essentially no difference in the empirical results whether we used Deutsche Bank or Citi factors as right hand side variables.

${ }^{10}$ Monthly data for this index are available at the AFX web site (http://www.ljmu.ac.uk/LBS/93557.htm). We are grateful to Jason Laws from the Liverpool John Moore University for providing daily data. We transformed the daily returns into weekly returns by using the Wednesday observations.
} 
weighted portfolio of three moving average rules (32, 61 and 117 days). ${ }^{11}$ Earlier research by Lequeux and Acar (1998) showed that this measure was a good proxy for a trend-following style among professional managers. The AFX Index is a well established proxy for trend-following strategies. It has been used for a number of years in various research papers, and therefore is known to researchers in this field.

\section{$\underline{\text { Value Factor }}$}

We use the Deutsche Bank FX PPP Index as the proxy for the returns of a value strategy. To gauge relative value, Deutsche Bank prepares a ranking based on the average daily spot rate over the last three months divided by the PPP exchange rate as published annually by the OECD. The FX PPP index reflects the return of being long the 3 currencies with the highest rank (undervalued currencies) against being short the 3 currencies with the lowest rank (overvalued currencies) within G10 currency universe. The Bloomberg code for this factor is DBPPPUSF Index.

\section{Currency Volatility Factor}

We use the Deutsche Bank Currency Volatility Index as the proxy for foreign exchange volatility. This index is calculated as the weighted average of 3-month implied volatility for nine major currency pairs (as provided by the British Bankers Association) with weights based on trading volume in the BIS surveys. ${ }^{12}$ The Bloomberg code for this factor is CVIX Index.

\footnotetext{
${ }^{11}$ The seven currency pairs are EUR-USD, USD-JPY, USD-CHF, GBP-USD, EUR-JPY, EUR-GBP, and EUR-CHF.

${ }^{12}$ The nine currency pairs are EUR-USD, USD-JPY, USD-CHF, USD-CAD, AUD-USD, GBP-USD, EUR-JPY, EUR-GBP, and EUR-CHF.
} 


\section{Empirical Results on Currency Return Indices}

\section{Grouping Managers into Fund of Funds}

To measure the overall returns for managers included on DB FXSelect, we construct several portfolios representing all available funds and certain subsets of funds. The first "fund-of-funds" (FoF) portfolio is compromised of equally weighted positions in each of the funds available on the platform on every Wednesday over the sample period. The return on this index can be defined as:

$$
R_{F O F, t}=\sum_{j=1}^{n_{t}} R_{j, t} / n_{t}
$$

where

$R_{j . t}$ is the weekly return for manager $j$ at time $t$

$n_{t}$ is the number of managers available on the platform at time $t$

This portfolio is rebalanced weekly with newly listed funds added and "dead" funds excluded from our fund-of-funds portfolio. As a result, every one of the 80 managers who were on the platform between April 2005 and March 2008 is included in our fund-of-funds index during their active period on the platform. From Figure 3, we see that $n_{t}$ ranges from a low of 22 funds in April 2005 rising steadily to a high of 65 funds in December 2006 and then levelling off. The FoF portfolio is our primary gauge of performance of managers on the DB FXSelect platform and represents an investable index. 
Figure 4 plots the cumulative performance of the FoF portfolio. The performance is positive, highlighting the attraction of currency as an alternative asset class. ${ }^{13}$ However, almost all of the performance is generated in the last 12 months. This performance pattern is consistent with the performance of the Parker FX index and the BCTI (see Table 1). ${ }^{14}$

To gain additional perspective on the performance of funds on the DB FXSelect platform, we construct two other portfolios, one consisting only of "dead" funds, i.e. the funds which were no longer on the platform in April 2008, and a second portfolio of "live" funds, i.e. those that were still active as of April 2008. The returns on these two funds are defined in an analogous way to our FoF, namely

$$
\begin{aligned}
& R_{D, t}=\sum_{j=1}^{n_{D, t}} R_{j, t}^{D} / n_{D, t} \\
& R_{L, t}=\sum_{j=1}^{n_{L, t}} R_{j, t}^{L} / n_{L, t}
\end{aligned}
$$

where

$$
\begin{aligned}
& R_{j, y}^{D} \text { is the weekly return for manager of dead fund } j \text { at time } t \\
& R_{j, y}^{L} \text { is the weekly return for manager of live fund } j \text { at time } t
\end{aligned}
$$

\footnotetext{
${ }^{13}$ The annualized Sharpe ratio of the FoF portfolio is 0.56 , comparable with the Sharpe ratios of the S\&P 500 index (0.30), MSCI World index (0.71) and the Lehman Global Aggregate bond index (0.75) during this period. Furthermore, the attraction of currencies as an alpha source is visible trough the low correlation with the other asset classes. The correlation of the returns on the FoF portfolio with the returns on the S\&P 500, MSCI World and Lehman Global Aggregate indices is $-0.4 \%, 12 \%$ and $23 \%$, respectively. The Sharpe ratio is computed as the average excess annualized monthly return (including dividends) divided by the annualized standard deviation of the excess returns. We use the 1- month LIBID (LIBOR less 12.5 bps) as the risk free rate.

${ }^{14}$ The correlation over this 3-year period between the monthly returns on the FoF portfolio and the monthly returns on the Parker FX index and the returns on the BCTI is $67 \%$ and $65 \%$, respectively.
} 
$n_{D, t}$ is the number of managers classified as dead as of April 2008 but available on the platform at time $t$

$n_{L, t}$ is the number of managers classified as living as of April 2008 and available on the platform at time $t$

For example, the dead portfolio would have invested in 7 funds as of April 2005, increasing to 20 at the end of 2006 and consisting of only one manager in March 2008 (see Figure 3). The number of living funds reached 59 in March 2008, Compared to the investable FoF index, our "Dead" and "Live" portfolios represent an "in-sample" experiment, which could be conducted only by looking backwards as we did not know which funds are going to die or remain on the platform. The cumulative performance of these two portfolios as shown in Figure 5 clearly differs and we will analyze this more closely in the next section.

\section{$\underline{\text { Regression Results on Return Indices }}$}

Following the approach in PL (2008), we estimate equation (1) using 156 weekly observations over the 3-year sample period, April 2005 - March 2008. We regress the returns of these 3 portfolios (FoF, Live and Dead) on the four risk factors described in the previous section. Alpha is the estimated intercept term, i.e. that portion of excess returns not explained by the four factor model, or

$$
\hat{\alpha}=R_{t}-\sum_{i} \hat{\beta}_{i} F_{i, t}
$$

Overall, the results in Table 2 support the four-factor model of currency trading returns. The model explains roughly $53 \%$ of the variability of the "FoF" portfolio

Over a longer period, from February 1987 to April 2008, the correlation between the returns on the Parker FX index and the returns on the BCTI is $90 \%$. 
returns. Trend appears to be the most significant factor. The trend coefficient is 0.40 , larger than for any other factor and highly significant. On average, the managers on the FXSelect platform seem to rely on trend-following. The trend factor alone explains $40 \%$ of the variability of the excess returns of the "FoF" portfolio (we have regressed the returns of "FoF" portfolio on each individual factor, but do not report the results). The carry coefficient is also positive and significant. The value coefficient is significant but negative, indicating that on average managers were positioned to profit from further deviations from PPP. The volatility coefficient is positive but not significant at the $10 \%$ level in a 2 -tail test.

Our point estimate for alpha in the "FoF" portfolio is zero and not significant. This result implies that managers included in the FXSelect platform were not able to generate alpha on average between April 2005 and March 2008. This confirms the presumption in the market that this period has been extremely challenging for currency managers. It is also consistent with previous research (PL 2008) that as a group, currency managers were not able to generate significant alpha returns over the long run (between 1990 and 2006). The returns in our sample are gross of fees, which means that the average alpha would be negative after management fees. Managers often charge a $2 \%$ per annum management fee and $20 \%$ performance fee, but fees do vary.

As the population of funds in the FXSelect platform changed over the 3-year period, it is interesting to explore differences in the performance of Live versus Dead funds, as defined by equations (3) and (4). Figure 5 reveals that live funds achieved a cumulative value of 108.7 far better than dead funds where value sank to only 91.6 
after 3 years. Put differently, the live funds earned about $2.8 \%$ per annum (with an information ratio of 0.91 ) compared to dead funds which earned $-2.8 \%$ per annum (with an information ratio of -1.21). ${ }^{15}$ We examine the performance of live and dead funds more closely with various regression tests. Several observations stand out in Table 2.

First, the alpha for the "Live" portfolio is quite high at almost 3 bps per week (or $1.4 \%$ per year). Although, not significant, this alpha suggests that this group of managers might have at least roughly covered their management fees. The alpha for the "Dead" portfolio is negative and significant. The "dead" managers lost about 6.5 bps per week (or roughly $3.3 \%$ per year). A t-test for the equality of the alphas of the "Live" and the "Dead" portfolio rejects the null hypothesis of equal means at the $95 \%$ confidence level (p-value $=0.0107)$. This may well explain why the "dead" funds exited the trading platform.

Second, the "live" managers have a positive and significant carry coefficient, but the "dead" managers have a negative and significant carry coefficient. Both groups are significantly exposed to trend, although the "live" managers have almost twice as much trend exposure as the "dead" managers. This is a very interesting result as it suggests that "betting against carry" was an important reason why the "dead" managers underperformed. There has been a presumption in the market, that the recent underperformance of trend-following rules (the AFX is roughly flat in the period under consideration) has been the main reason for the disappointing performance of professional currency managers. Our results suggest that this

\footnotetext{
${ }^{15}$ An information ratio is the ratio of excess returns divided by their standard deviation.
} 
presumption may be misplaced. Our results show that the strong performance of carry (up to the beginning of the credit crunch in July 2007) had a substantial impact on managers who were betting against the carry strategy. Ironically, although some managers might have been punished due to heavy exposure to carry after July 2007 (e.g. NZD/JPY dropped 23\% between July 24, 2007 and August 16, 2007), many managers seem to have suffered heavy losses prior to that by betting against carry.

Third, the "live" managers have a negative and significant exposure to the value factor and the "dead" managers have a positive, but not significant value coefficient. Betting against PPP and for continuation of departures from fair value seems to have helped the surviving managers to remain on the platform.

Finally, the R-square for the "live" managers (55\%) is much higher than the $18 \% \mathrm{R}$ square for "dead" managers. Anson (2008) theorizes that there is a trade-off between beta style returns and alpha returns. In short, strategies that mimic an index cannot earn returns that lead to outperformance. In an earlier study (PL, 2008), we found evidence supporting Anson's conjecture, namely that currency managers with high Rsquare tend to have lower alpha, and vice versa. In the DB FXSelect sample which includes live and dead funds, our results suggest that live managers tended to track the four factors more closely, earning beta returns, which should have helped them remain in operation. And indeed the live managers in our sample earned positive (although not significant) alpha as well. With weaker linkages to the four style factors, the dead managers were positioned to execute "pure" alpha seeking strategies. Unfortunately, in this instance, the dead managers realized significant negative alpha. 
So while being an alpha manager is good in the sense that it would justify active management fees - it is good only as long as the managers are able to deliver positive returns. Beta chasers might find it more difficult to justify alpha fees, but sticking close to the benchmark (the four trading strategies) has apparently helped them to stay in business. This result is consistent with a common strategy in the asset management industry. The bulk of assets under management are allocated close to the benchmark as large deviations from the benchmark expose the manager to significant business risk in case of underperformance.

To better understand this anomaly of high (low) R-square and high (low) alpha, we re-estimated the regressions for "live" and "dead" funds in Table 2 including quadratic terms for each factor to test for market timing. ${ }^{16}$ The results for "live" managers show positive and significant timing ability with respect to the trend following factor (see Table 3). Once this effect is included, the point estimate for alpha for live managers drops to -2.7 bps per week from +2.7 bps per week., suggesting that all of their alpha could be accounted for by timing skills in trend following. ${ }^{17}$

The "dead" managers also have positive timing skill in trend, but on the other hand, they exhibit negative timing skills for volatility. ${ }^{18}$ The actual returns of "dead" managers were made worse by taking positions that faltered when volatility increased.

\footnotetext{
${ }^{16}$ Lo (2007) proposes a quadratic term as a way to detect market timing skills.

${ }^{17}$ Having estimated the alpha of the live managers with the 4-factor model and with the market timing model (8-factors) we were able to test for equality in the alphas. A t-test rejects the null hypothesis of equal means at the $90 \%$ confidence level ( $p$-value $=0.0866$ ). Thus, market timing has significantly contributed to the superior returns of the live managers.

${ }^{18}$ The coefficient of the squared volatility term is significant only at the $10 \%$ level. However, in an alternative specification of the market timing model, which omits the volatility factor, the dead managers exhibit a significant negative market timing ability in the carry strategy at the $5 \%$ level.
} 
Overall, our analysis suggests that market timing skills had no significant positive impact on the returns of dead managers. ${ }^{19}$

\section{Empirical Results for Individual Managers}

\section{$\underline{\text { Full three-year sample period }}$}

Table 4 summarizes the results for the individual currency managers with a track record spanning the entire 3-year period. The first row of Table 4 shows the results for an equally weighted portfolio ("Index" portfolio) consisting of all 15 managers. As in the case of the "Live" and "Dead" portfolios, this is a backward looking exercise as we did not know which managers who were on the platform in April 2005 would remain until March 2008.

For the 15 individual managers, Table 4 shows that trend was the most important factor over the 3-year period. Trend is significant for more than half of the managers (8). Carry is significant for 7 managers, but three of the managers had a significant negative exposure to carry. It seems that while $25 \%$ of the managers were exhibiting carry exposure, a similar number were betting on liquidation of carry trades. Value was significant only for 5 managers and four of these managers had a negative exposure to value, i.e. they were betting for further deviation from PPP. Volatility was significant for 4 managers - two managers would have benefited from falling volatility environment (the volatility coefficient was negative and significant) and two managers would have benefited from rising volatility environment (positive and significant volatility beta). Finally, none of the managers was able to deliver

\footnotetext{
${ }^{19} \mathrm{~A}$ t-test for the equality of the alphas estimated with the 4-factor model and with the market timing model did not rejects the null hypothesis of equal means for the dead managers. Market timing did not improve the returns of the dead managers as the positive market timing in trend was offset with negative market timing in volatility.
} 
significant alpha as defined by our four factor model. Manager L28 was the best of all with alpha estimated at 12 bps per week (about $6.0 \%$ per year) and significant at the $90 \%$ confidence level.

Table 5 reports the annualized excess returns, standard deviations and information ratios for these 15 managers. The average excess annual return is positive, ranging from $-3.30 \%$ (L58) to $16.10 \%$ (L29) and the volatility ranges from $3.53 \%$ (L10) to $19.28 \%$ (L29). The average information ratio is 0.37 . However, this average information ratio overstates the performance of the average manager during this challenging period as it is not adjusted for survivorship bias. The fourth column of Table 5 ranks the managers by their information ratio. Manager L28 is ranked first (IR equals 1.17) and manager L58 is ranked last (fifteen) with an information ratio of -0.35 .

We also report the annualized alpha return, the standard deviation of alpha returns (tracking error) and the alternative information ratio (IR*) as defined in PL (2008). ${ }^{20}$ Rank* is therefore the ranking of the managers by their IR*. Note that manager L35 experiences the largest improvement in ranking; he jumps to place $8^{\text {th }}$ from place $12^{\text {th }}$. This is not a surprise as his R-square was the second smallest (see Table 3). Less than $6 \%$ of the variability of his returns could be explained by the exposure to the four factors.

\footnotetext{
${ }^{20}$ The information ratio (IR) is defined as the ratio of excess returns to their standard deviation. If we assume that all returns are excess returns, then $I R=R_{j} / \sigma\left(R_{j}\right)$, where $R_{j}$ is the annualized average excess return and $\sigma\left(R_{j}\right)$ is its annualized standard deviation. Using equation (1) to estimate alpha, PL define the alternative information ratio as $I R^{*}=\dot{\alpha}_{j} / \sigma\left(\dot{\alpha}_{j}\right)$.
} 
The average IR* is smaller $(0.24)$ than the average IR $(0.37)$. This suggests that significant part of the returns of the average manager could be contributed to exposure to the four risk factors and it is not pure alpha.

\section{$\underline{\text { Successive one-year samples }}$}

To investigate performance and style persistence, we estimate equation (1) using 52 weekly observations on successive one-year periods. Table 6 to 8 show the results for three periods: April 2005 to March 2006, April 2006 to March 2007 and April 2007 to March 2008. For each sub-period, we include those managers who have a full performance track record in the respective period. We start with 22 funds in the first sub-period. Twenty-one of these managers have also a full performance history in the second sub-period (manager D10 exited the platform in January 2007 - after a total return of $-12 \%$ since entering) and is not included in the second sub-period. An additional 31 managers joined the platform between May 2005 and April 2006 and have a full track record available trough the second sub-period. Thus, the total number of managers with a performance track record between April 2006 and March 2007 rises to 52. The last sub-period contains 46 currency managers. Twenty-one managers did not make it through the last 12 months after joining the platform sometime before April 2007. This illustrates again the magnitude of the survivorship bias and the necessity to include the performance of the "dead" funds in the analyses.

Several results stand out from the analysis. First, the data continue to support the four factor model over shorter periods, specifically for these three one-year sub-periods. To gauge the explanatory power of the model on an index level, we have proceeded as in the section above and constructed three equally-weighed portfolios, which consist 
of the managers with a full history in the respective sub-period. These portfolios/indices are in the row labelled "Index." In the three 12-month periods ending March 2006, March 2007 and March 2008, the four factors explain 50.0\%, $61.3 \%$ and $67.3 \%$ respectively of the variability of the returns in these portfolios. Looking at individual managers, the median R-squares are $19.7 \%, 20.8 \%$ and $26.2 \%$ over the three successive periods. On a year-by-year basis, between 10-25\% of individual managers exhibit an R-square exceeding 50\% (the highest R-square, 81\%, was recorded for manager L9 in the third sub-period), while roughly the same fraction produce an R-square under $10 \%$.

Second, the importance of trend seems to be declining while the importance of carry seems to be rising and exceeded trend in the last sub-period. Table 9 shows the fraction of the managers with significant exposure to each individual factor for the different sub-periods. While trend was the most important factor between April 2005 and March 2006 with $50 \%$ of the managers significantly exposed to it, trend was only second to last in terms of importance between March 2007 and April 2008 with only $28 \%$ of the managers significantly exposed to it. Ironically, this was also the period where trend started to perform well again as a strategy. Trend yielded $0.1 \%$ in the first sub-period, $1.11 \%$ in the second sub-period and $6.12 \%$ in the last sub-period. Carry shows a similar picture: it yielded its worst performance $(-3.4 \%)$ in the third subperiod, where $50 \%$ of the managers were significantly exposed to it (18 with positive coefficient and 5 with a negative coefficient). This suggests a reason to avoid not only "crowded" trades, but also "crowded" styles as well. When a trading style becomes "crowded" it appears as if performance in that style declines. ${ }^{21}$

${ }^{21}$ The relationship between crowding and performance is a topic we leave for future research. 
Third, only a small fraction of managers (10-17\%) were significantly exposed to value and volatility with the exception of the last sub-period in which value was the second most important factor (after carry) with $37 \%$ of the managers exhibiting significant value beta. However, while half of these managers were betting for meanreversion towards the PPP exchange rate, the other half was betting for further deviation from PPP.

\section{$\underline{\text { Performance persistence }}$}

To investigate the question of whether managers who have been performed well in the past continue to perform well in the future, we follow Aggarwal and Jorion (2008) and report the results for the following regression

$$
\alpha_{j t}=\delta_{0}+\delta_{1} \alpha_{j t-1}+\mu_{j t}
$$

Where $\alpha_{\mathrm{j}}$ is the excess return for fund manager $j$ that is not explained by the four factors, or

$$
\hat{\alpha}_{j}=R_{j, t}-\sum_{i} \hat{\beta}_{i, j} F_{i, t}
$$

Table 10 presents the results. We have 21 funds in the second sub-period, which were also active in the first sub-period and 37 in the third sub-period, which were also active in the second sub-period. Neither regression yields a significant coefficient on the previous year's alpha. This result suggests that past excess performance as measured by alpha is not related to future performance. Although, $\delta_{1}$ is positive, it is not significantly different from zero. 
As an alternative way to gauge performance persistence, we form portfolios based on performance quartiles. The performance of the best performing (ranked by alpha return, performance in the first quartile Q1) managers in the first sub-period is aggregated by constructing an equally weighted portfolio, labelled the Q1 portfolio. We also aggregate the performance of the bottom quartile managers into a Q4 portfolio. Comparing the performance of the Q1 and the Q4 portfolio in the second sub-period is a way to gauge persistence. ${ }^{22}$ The average weekly alpha for the Q1 portfolio in the second sub-sample was 1.4 bps (or $0.7 \%$ annualized), higher than the average weekly alpha of the Q4 portfolio -11 bps (or $-5.8 \%$ annualized). This is an indication for some persistence. However, a t-test for the difference in the means does not reject the hypothesis of equal average alpha.

We performed the same exercise for the third sub-period (comparing the performance of managers who were in the top quartile in the second sub-period with the performance of the managers who were in the bottom quartile in the second subperiod). Again, there is no evidence of performance persistence. The average alpha for the Q4 portfolio was even higher (3.6 bps or 1.88\% annualized) than the average alpha of the Q1 portfolio (2.8 bps or $1.46 \%$ annualized). Thus, the managers who were in the bottom quartile (ranked on alpha) between April 2006 and March 2007 outperformed during the following 12 months those managers who were in the top quartile between April 2006 and March 2007. Again, a t-test for the difference in the means did not reject the hypothesis of equal average alpha.

\footnotetext{
${ }^{22}$ Managers who did not survive during the following 12 months are included as long as they are on the platform. Although Carpenter and Lynch (1999) recommend comparing top and bottom decile portfolios, because of our small sample size, we follow Aggarwal and Jorion (2008) and compare top and bottom quartile portfolios
} 
Note, that the methodology in equation (6) estimates the average persistence (from year $t$ to year $t+1$ ) for a cross section of managers rather than the persistence over time for a specific manager. ${ }^{23}$ Thus, our rejection of persistence does not mean that not a single manager is able to deliver persistent performance. Indeed, in a previous study Levich and Pojarliev (2008) report that of the 8 managers with significant alpha over a 3-year period (2001-03), fully 7 managers continued to make positive alpha in the following 3-year period (2004-06). ${ }^{24}$ No manager showed significant alpha in the second period who did not produce alpha in the first sub-period. Although, the average manager does not show persistence, some skilled managers do.

\section{$\underline{\text { Style persistence }}$}

To check for style persistence, we perform regressions similar to (6) estimating cross sectional regressions for each one of the four betas. Table 11 reports the results.

The results indicate strong persistence for the trend factor and carry factor. The coefficients for both carry and trend for year t-1 are positive and highly significant. This suggests that managers who are exposed to carry in period $\mathrm{t}-1$ are likely to maintain significant carry exposure in period t. The same result is valid for the trend factor. Value is persistent only from the second into the third sub-period, but not from the first into the second sub-period. We do not detect persistence for volatility, which is also consistent with the finding that this is the least important factor.

\footnotetext{
${ }^{23}$ The later would require many estimates of alpha for manager $\mathrm{j}$ over successive periods to estimate that manager's $\delta_{1}$ persistence factor.

${ }^{24}$ We should caution that in this paper our tests for performance persistence rely on performance measured over only one year. The one-year period may be too short to accurately access underlying performance. The differences between performance persistence when estimating performance over different periods (1-year, 3-years and 5-years) is a topic we leave for a future research. In addition, we
} 
Style persistence can be interpreted as either good or bad news. It is good news, since an investor might expect that his currency manager will continue to follow the same investment style. This would allow endowment and pension fund sponsors to issue mandates that diversify their style exposure. On the other hand, it is bad news, since style persistence would indicate less market timing ability, i.e. switching between styles when one style fails to perform well.

\section{Conclusions}

In this paper, we estimate cross sectional annual alphas for professional currency managers for the three years between April 2005 and March 2008. With data for all managers on the DB FXSelect platform since inception, even those who eventually exit, we can control for survivorship and backfill bias.

The results confirm results from our earlier study, namely that four factors representing the returns of well-known currency trading strategies and currency volatility explain a significant part of returns of professional currency managers. We extend those results by demonstrating that the relationship is present in a different time period (2005-08 versus 2001-06 in the earlier study) and for shorter intervals of 3 years and 1 year. More importantly, obtaining annual alphas and style betas allows us to test for performance and style persistence. We find no indication of performance persistence, but we do find statistically significant evidence of style persistence.

These results have important implications for the investment management industry. Plan sponsors should be careful when selecting currency managers based only on past

examine only two intervals, which may be too few to detect persistence especially if persistence is weak. 
performance data. As in other venues of investment management, in this sample of currency managers it appears that past performance is no indication for future performance. On the other hand, style persistence indicates that choosing currency managers with different styles makes sense as they are likely to maintain their style, and thus continue to offer a diversification benefit. Plan sponsors usually seek to hire more than one currency manager with different styles to obtain diversification benefits. From this perspective, our evidence for style persistence is welcome. However, style persistence may imply that individual managers are less able to exploit market timing ability.

In addition, we document some significant differences between managers who did not survive our three-year sample and managers who were still alive and active in April 2008. Not surprisingly, we find that surviving managers produced alpha that was higher than exiting managers, and with a difference of about 9.5 bps per week (or nearly $5 \%$ per year), the difference is both statistically and economically significant. Our analysis suggests that living mangers generally tracked our four factors more closely (with a higher R-square) than managers that would eventually die. Sticking closer to the "benchmarks" has helped some managers to stay in business. Components of their investment strategies, as evidenced by the sign of factor coefficients, varied as well. Contrary to the presumption in the market that the recent underperformance of trend-following strategies was the main reason for the lacklustre performance of currency managers over the last three years, we found that "betting for liquidation of carry strategies" caused more damage for some managers. Additional tests suggest that live managers owe some of their success to timing skills in the trend 
following strategy, whereas dead managers demonstrated negative timing with respect to volatility.

Overall, our results lend further support to the notion that style factors explain a substantial part of returns for indices composed of professional currency fund managers. While the track records of individual managers - their strategies and performance, as well as their longevity - vary considerably, managers appear to have two things in common - a lack of performance persistence and a tendency for style persistence.

Our results are subject to the limitation that we analyzed only the currency managers listed on the DB FXSelect platform. Furthermore, since the platform was launched in March 2005, the available data cover a relative short period of 3 years (2005-08). Further research may help to understand what factors influence the performance of individual managers. 


\section{References}

Aggarwal, R.K. and P. Jorion. 2008. "The Performance of Emerging Hedge Fund Managers," working paper.

Anson, M. 2008. "The Beta Continuum: From Classic Beta to Bulk Beta," Journal of Portfolio Management, vol. 34, no. 2 (Winter): 53-64.

Burnside, C., M. Eichenbaum, I. Kleschelski, and S. Rebelo. 2006. "The Returns to Currency Speculation,” NBER working paper 12916.

Carpenter, J.N. and A.W. Lynch. 1999. "Survivorship bias and attrition effects in measures of performance persistence," Journal of Financial Economics, vol. 54, no 3 (December): 337-74.

Citibank, CitiFX Risk Advisory Group. 2003. "Investor Strategy: A Fresh Look at Purchasing Power Parity."

Deutsche Bank. "Currencies: Value Investing,” March 29, 2007.

Froot, K. and R. Thaler. 1990. "Anomalies: Foreign Exchange," Journal of Economic Perspectives, vol. 4, no. 3 (Summer): 179-92.

Gross, W. 2005. "Consistent Alpha Generation through Structure," Financial Analysts Journal, vol. 61, no. 5 (Sept-Oct): 40-43.

Irvin, S. and C. Park. 2007. "What Do We Know About the Profitability of Technical Analysis?" . Journal of Economic Surveys, vol. 21, no. 4, pp. 786-826.

Lequeux, P. and E. Acar. 1998. "A Dynamic Benchmark for Managed Currencies Funds" European Journal of Finance, vol. 4, no.4 (December): 311-30.

Levich, R. and M. Pojarliev. 2008. "Separating Alpha and Beta Returns: A New Benchmark for Currency Managers", at www.VoxEU.org, Centre for Economic Policy Research policy portal.

Lo, Andrew W. 2007. "Where Do Alphas Come From? A New Measure of the Value of Active Investment Management," MIT working paper.

Neely, C. J., P. A. Weller, and J.M. Ulrich. 2007. "The Adaptive Markets Hypothesis: Evidence from the Foreign Exchange Market," working paper, Federal Reserve Bank of St. Louis.

Pojarliev, M. and R.M. Levich. 2008. "Do Professional Currency Managers Beat the Benchmark?" Financial Analysts Journal, (forthcoming). 
Figure 1: Cumulative Excess Returns of Currency Trading Strategies

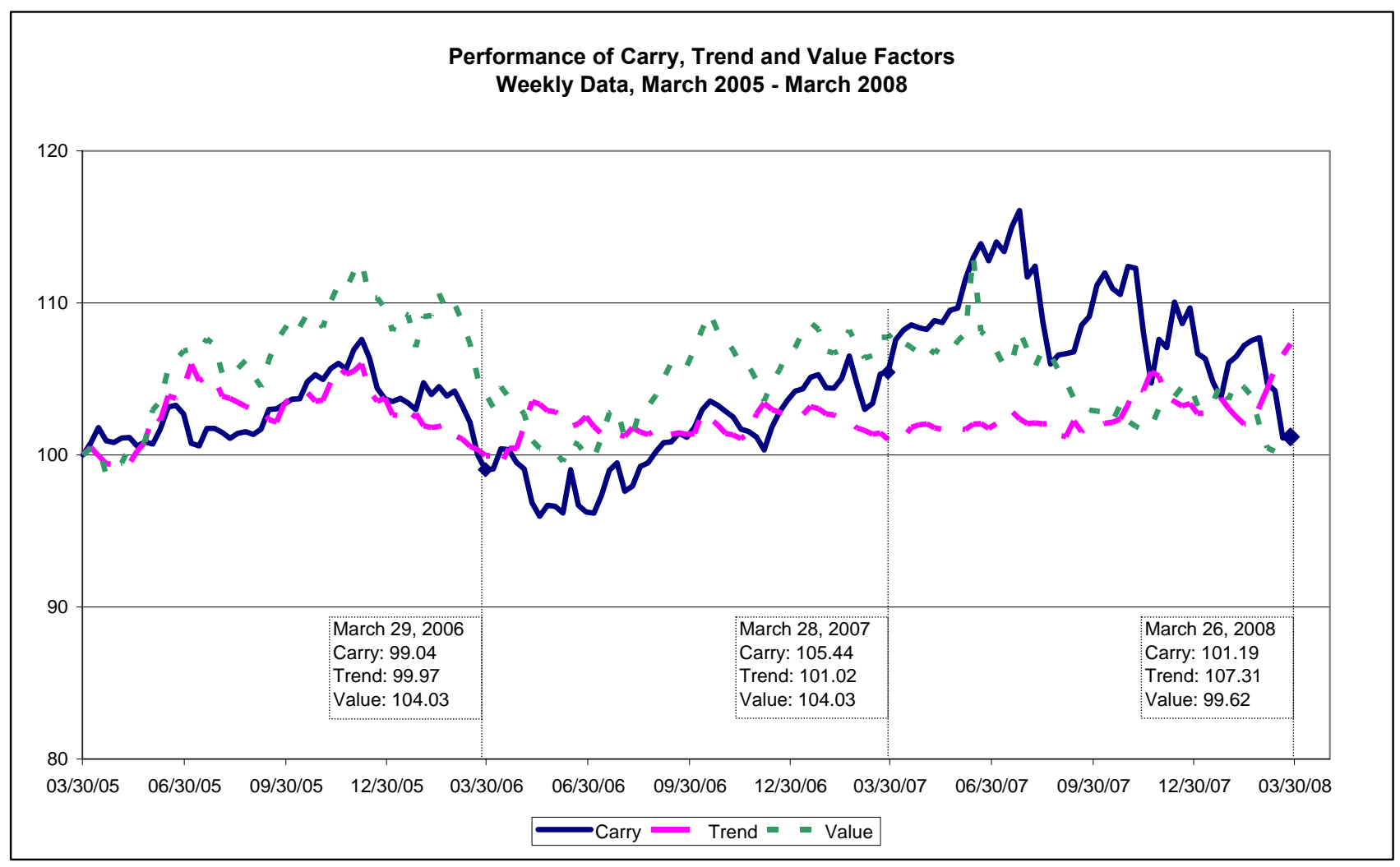

The Carry Index return is represented by the Deutsche Bank G10 Harvest Index as the proxy for the returns of a carry strategy. This index reflects the return of being long the 3 high-yielding currencies against being short the 3 low-yielding currencies within G10 currency universe. The index is rebalanced quarterly.

The Trend Index return is represented by the AFX Currency Management Index. The AFX Index is based on trading in seven currency pairs (EUR-USD, USD-JPY, USD-CHF, GBP-USD, EUR-JPY, EUR-GBP, and EUR-CHF) weighted by their volume of turnover in the spot market, with returns for each pair based on an equally-weighted portfolio of three moving average rules (32, 61 and 117 days).

The Value Index return is represented by the Deutsche Bank FX PPP Index. The average daily spot rate over the last three months is divided by the PPP exchange rate as published annually by the OECD and ranked. This index reflects the return of being long the 3 currencies with the highest rank (undervalued currencies) against being short the 3 currencies with the lowest rank (overvalued currencies) within G10 currency universe.

Source: Deutsche Bank, Bloomberg, Liverpool John Moores University 
Figure 2: Currency Volatility

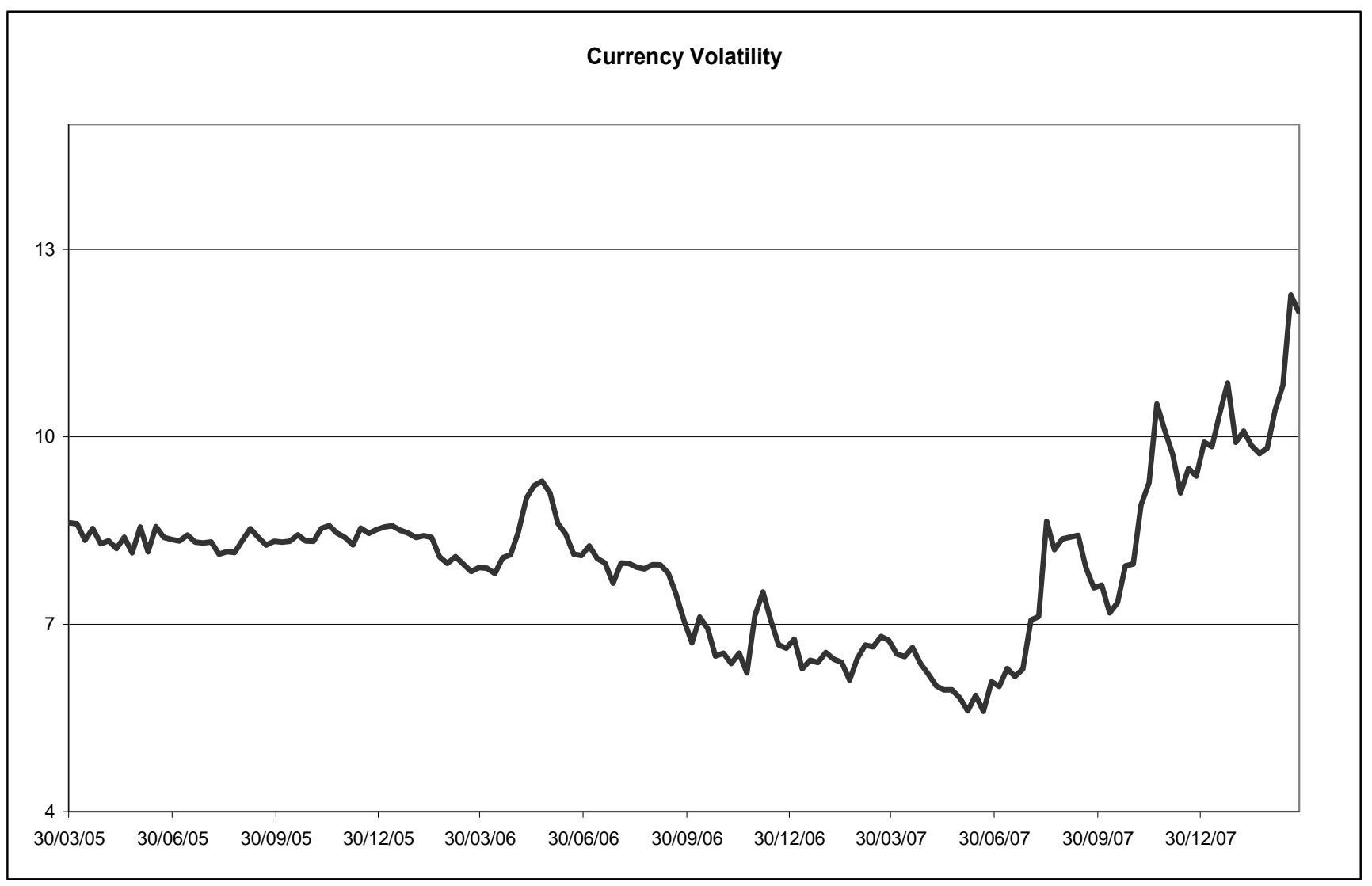

The Deutsche Bank Currency Volatility Index as the proxy for foreign exchange volatility. This index is calculated as the weighted average of 3-month implied volatility for nine major currency pairs (EURUSD, USD-JPY, USD-CHF, USD-CAD, AUD-USD, GBP-USD, EUR-JPY, EUR-GBP, and EUR-

$\mathrm{CHF}$ ) as provided by the British Bankers Association with weights based on trading volume in the BIS surveys

Source: Deutsche Bank, Bloomberg. 
Figure 3: Number of Funds on the Deutsche Bank FXSelect Platform

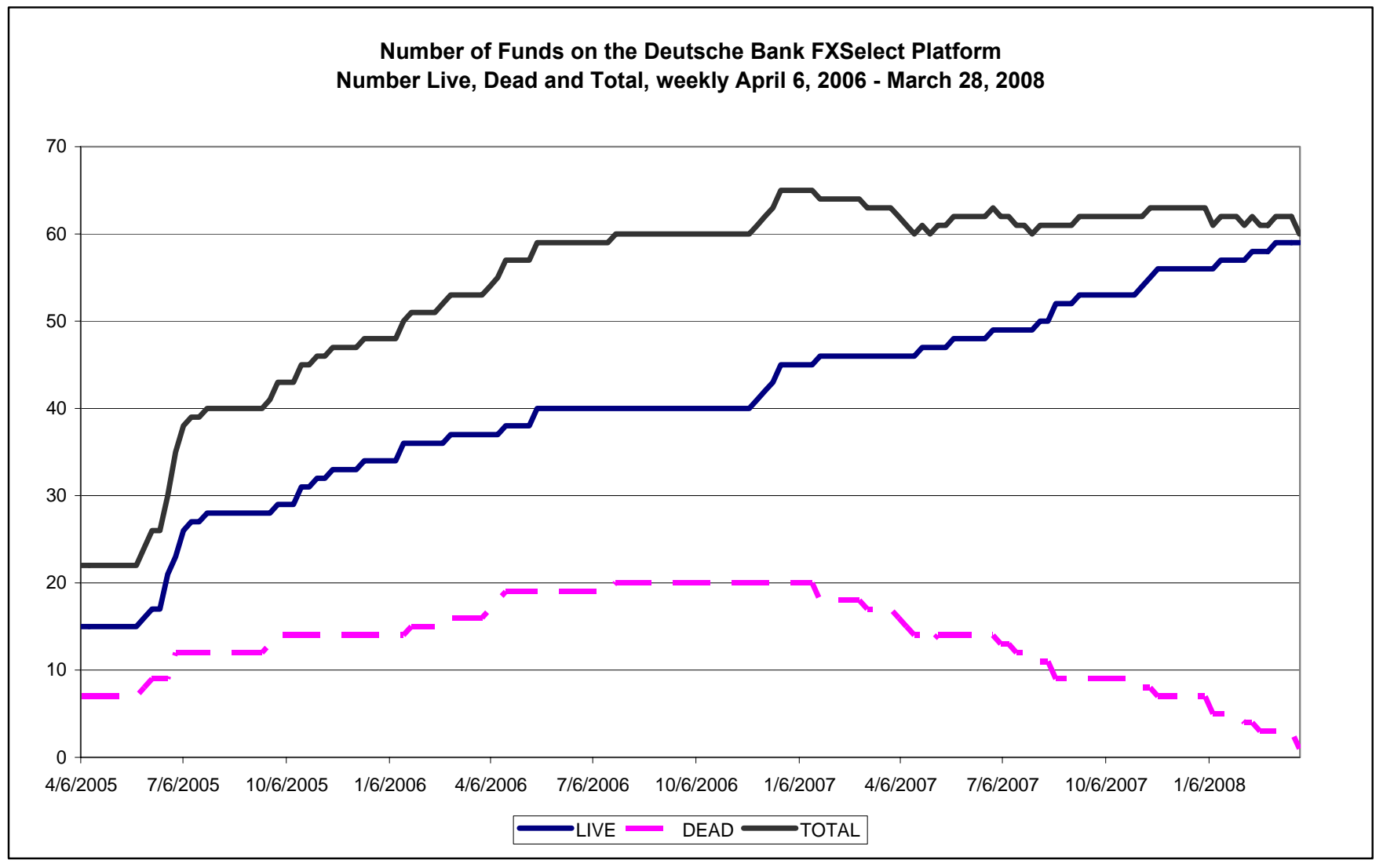

"Live" funds are those on the platform in week $t$ and still active and on the platform in April 2008.

"Dead" funds are those on the platform in week $t$ but inactive and no longer on the platform as of April 2008.

"Total" is the sum of "Live" and "Dead" funds on the platform in week $t$.

Source: Deutsche Bank and authors calculations. 
Figure 4: Cumulative Performance of the "FoF" Portfolio

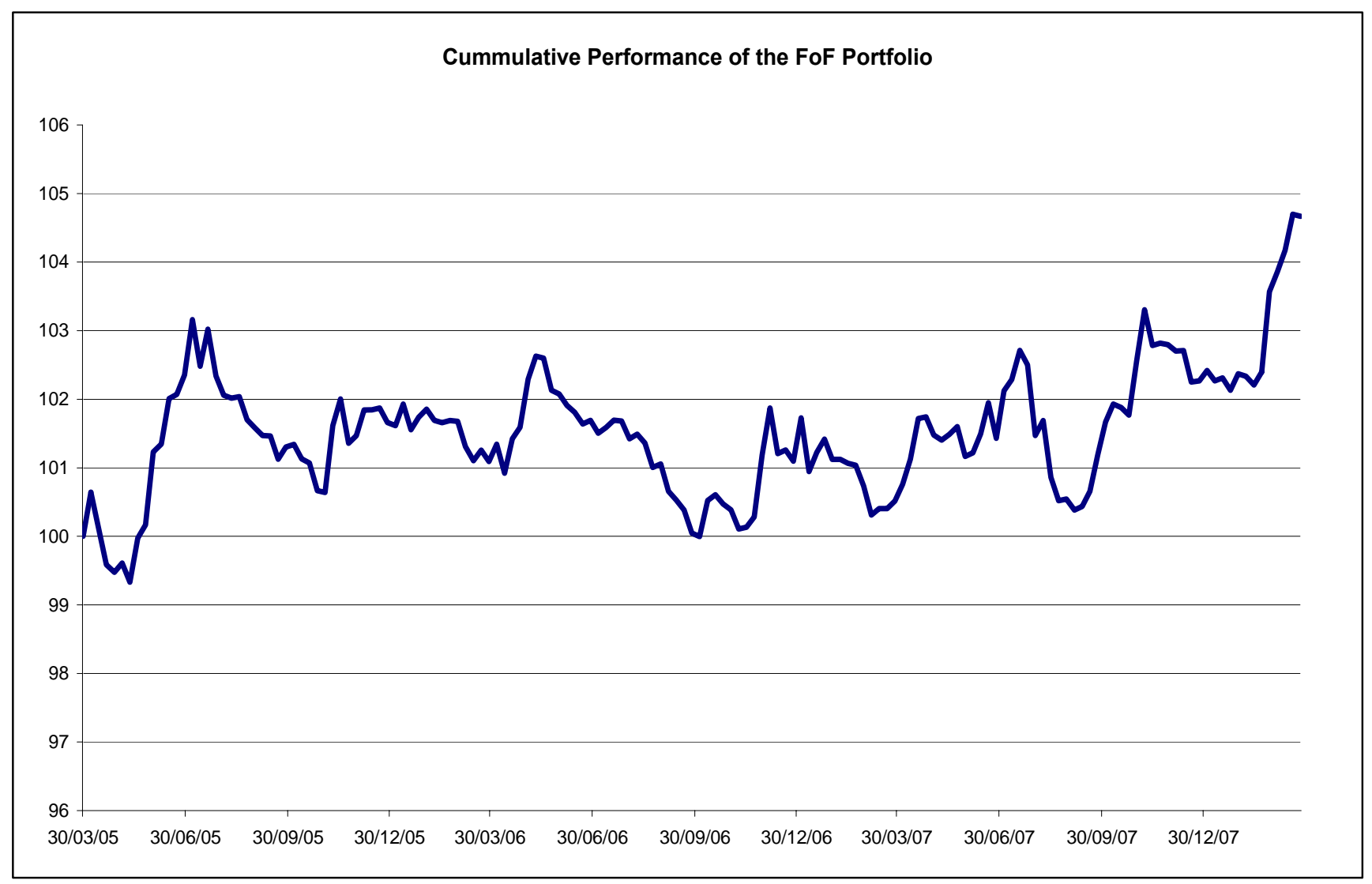

This portfolio is an equally weighted portfolio of all funds on the Deutsche Bank FXSelect platform, rebalanced weekly with newly listed funds added and dead funds excluded from the portfolio.

Source: Deutsche Bank and authors calculations. 
Figure 5: Cumulative Performance of the "Live" and "Dead" Portfolios

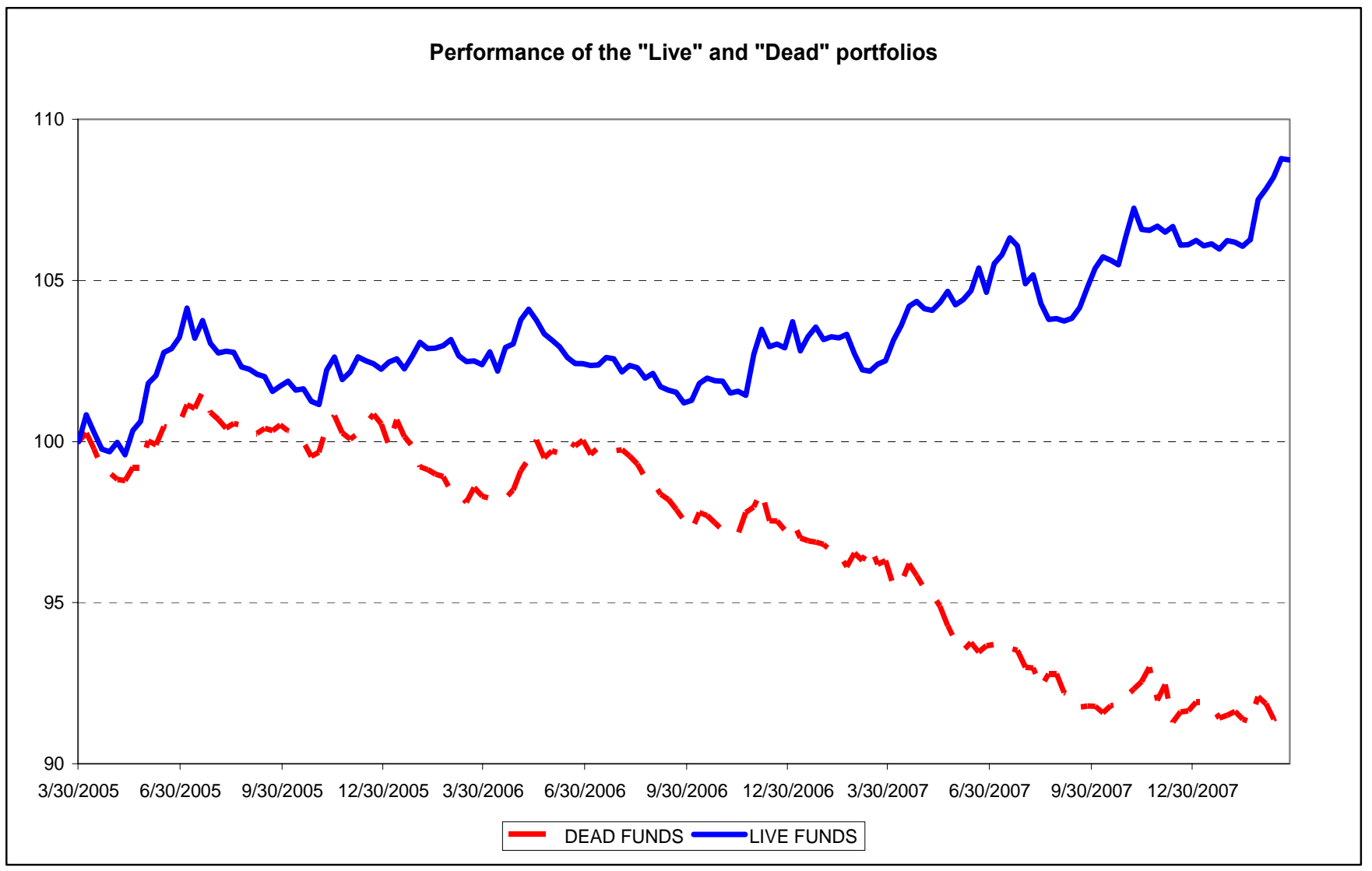

Cumulative performance on two portfolios of funds listed on the Deutsche Bank FXSelect platform. One portfolio consists only of "dead" funds, i.e. the funds which were no longer on the platform in April 2008, and a second portfolio consists of "live" funds, i.e. those that were still active as of April 2008.

Source: Deutsche Bank and authors calculations. 
Table 1: Cumulative Excess Returns of Currency Indices

\begin{tabular}{|c|c|c|c|c|}
\hline & $\begin{array}{c}\text { FoF Portfolio } \\
\text { DB FXSelect }\end{array}$ & $\begin{array}{c}\text { Parker FX } \\
\text { Index } \\
\text { Reported }\end{array}$ & $\begin{array}{c}\text { Parker FX Index } \\
\text { Scaled Returns }\end{array}$ & $\begin{array}{c}\text { Barclay } \\
\text { Currency } \\
\text { Traders Index }\end{array}$ \\
\hline $\begin{array}{c}\text { 1 year, } \\
\text { April 07 to March 08 }\end{array}$ & $4.08 \%$ & $2.44 \%$ & $0.77 \%$ & $1.23 \%$ \\
\hline $\begin{array}{c}\text { 2 years, } \\
\text { April 06 to March 08 }\end{array}$ & $3.54 \%$ & $0.00 \%$ & $-0.70 \%$ & $-1.51 \%$ \\
\hline $\begin{array}{c}\text { 3 years, } \\
\text { April 05 to March 08 }\end{array}$ & $4.66 \%$ & $-0.49 \%$ & $-1.42 \%$ & $-3.29 \%$ \\
\hline
\end{tabular}

The FoF portfolio is compromised of equally weighted positions in each of the funds available on the Deutsche Bank FXSelect platform on every Wednesday over the sample period. These are gross returns before taking fees into account. Source: Deutsche Bank.

Parker FX index reported excess returns are the net of fees returns on the FX Parker Index less the risk free rate. As a proxy for the risk free rate we use 1-month LIBID (LIBOR less 12.5 bps). Source: Parker Global Strategies, LLC and Bloomberg.

Parker FX Index scaled returns are the net of fees returns on the Parker FX index, in excess of short term interest rates and scaled to a 5\% volatility. Source: Parker Global Strategies, LLC.

Barclay Currency Traders Index returns are the net of fees returns on the Barclay Currency Traders Index less the risk free rate. As a proxy for the risk free rate we use 1-month LIBID (LIBOR less 12.5 bps). Source: BarclayHedge, British Bankers Association and Bloomberg. 


\section{Table 2: Regression Results for “Fund of Funds” Portfolios, April 2005 to March 2008}

Regression Results for $R_{j, t}=\alpha_{j}+\sum_{i} \beta_{i, j} F_{i, t}+\varepsilon_{j, t}$ for portfolios $\mathrm{j}=1, \ldots 3$.

Based on 156 weekly observations, 4/06/2005-3/26/2008

\begin{tabular}{|c|c|c|c|c|c|c|c|c|c|c|c|c|c|}
\hline & Alpha & T-Stat & $\begin{array}{l}\text { Beta } \\
\text { Carry }\end{array}$ & T-Stat & $\begin{array}{l}\text { Beta } \\
\text { Trend }\end{array}$ & T-Stat & $\begin{array}{l}\text { Beta } \\
\text { Value }\end{array}$ & T-Stat & $\begin{array}{c}\text { Beta } \\
\text { Volatility }\end{array}$ & T-Stat & $\begin{array}{c}\text { R- } \\
\text { Square }\end{array}$ & F-Stat & D-W \\
\hline "FoF" & 0.00001 & 0.31 & 0.14 & 6.03 & 0.40 & 10.88 & -0.08 & -3.85 & 0.12 & 1.53 & 0.534 & 43.30 & 2.21 \\
\hline "Live" & 0.00027 & 1.16 & 0.19 & 7.21 & 0.45 & 10.70 & -0.10 & -4.25 & 0.15 & 1.74 & 0.550 & 46.24 & 2.27 \\
\hline "Dead" & -0.00064 & -2.31 & -0.06 & -2.12 & 0.23 & 4.57 & 0.02 & 0.75 & -0.01 & -0.15 & 0.183 & 8.48 & 2.41 \\
\hline
\end{tabular}

The Deutsche Bank G10 Harvest Index is the proxy for the returns of a Carry strategy. This index reflects the return of being long the 3 high-yielding currencies against being short the 3 low-yielding currencies within G10 currency universe. The index is rebalances quarterly. Every quarter the currencies are re-ranked according to their current 3 months Libor rate. Source: Deutsche Bank and Bloomberg.

The AFX Index reflects returns on a trend following strategy involving three moving average rules applied to seven currency pairs, weighted by the volume of turnover in the spot market. Monthly data are available at http://cwis.livim.ac.uk/AFE/AFE docs/AFX Monthly.xls. Source: Liverpool John Moores University.

The Deutsche Bank FX PPP Index is the proxy for the returns of a Value strategy. The average daily spot rate over the last three months is divided by the PPP exchange rate as published annually by the OECD and ranked. This index reflects the return of being long the 3 currencies with the highest rank (undervalued currencies) against being short the 3 currencies with the lowest rank (overvalued currencies) within G10 currency universe. Source: Deutsche Bank and Bloomberg.

The Deutsche Bank Currency Volatility Index (CVIX index) is the proxy for the foreign exchange volatility. It is calculated as the weighted arithmetic average of the 3 months level of implied volatility for all major currency pairs (provided by BBA) and weighted by traded market volume. Source: Deutsche Bank and Bloomberg. 


\section{Table 3: Market Timing Model}

Regression Results for $R_{j, t}=\alpha_{j}+\sum_{i} \beta_{i, j} F_{i, t}+\sum_{i} \gamma_{i, j} F_{i, t}^{2}+\mu_{j, t}$

Based on 156 weekly observations, 4/06/2005-3/26/2008

\begin{tabular}{|c|c|c|c|c|c|c|c|c|c|c|c|c|c|c|c|c|c|c|c|c|c|}
\hline & Alpha & T-St. & $\begin{array}{c}\beta \\
\text { Carry }\end{array}$ & T-St. & $\begin{array}{c}\beta \\
\text { Trend }\end{array}$ & $\begin{array}{l}\text { T- } \\
\text { St. }\end{array}$ & $\begin{array}{c}\beta \\
\text { Value }\end{array}$ & T-St. & $\begin{array}{c}\beta \\
\text { Vol. }\end{array}$ & T-St. & $\begin{array}{c}\gamma \\
\text { Carry }\end{array}$ & T-St. & $\begin{array}{c}\gamma \\
\text { Trend }\end{array}$ & $\begin{array}{l}\text { T- } \\
\text { St. }\end{array}$ & $\begin{array}{c}\gamma \\
\text { Value }\end{array}$ & T-St. & $\begin{array}{c}\gamma \\
\text { Vol. }\end{array}$ & T-St. & $\mathbf{R}^{2}$ & $\begin{array}{l}\text { F- } \\
\text { Stat }\end{array}$ & D-W \\
\hline "Live" & $-2.7 \mathrm{bps}$ & -0.85 & 0.18 & 6.70 & 0.40 & 9.02 & -0.09 & -4.01 & 0.07 & 0.72 & -0.24 & -0.21 & 13.29 & 3.02 & 0.99 & 1.05 & 3.30 & 0.31 & 0.581 & 25.54 & 2.36 \\
\hline "Dead" & $-9 \mathrm{bps}$ & -2.41 & -0.09 & -2.91 & 0.15 & 3.03 & 0.04 & 1.40 & 0.01 & 0.09 & -1.23 & -0.95 & 17.09 & 3.35 & 0.79 & 0.72 & $\begin{array}{l}-20.2 \\
\end{array}$ & -1.65 & 0.278 & 7.09 & 2.43 \\
\hline
\end{tabular}

* In decimal form, the alphas are -0.00027 and 0.00090 for live and dead funds respectively.

See notes to Table 2 for explanation of factors. 
Table 4: Regression Results for Individual Currency Managers, April 2005 to March 2008

Regression Results for $R_{j, t}=\alpha_{j}+\sum_{i} \beta_{i, j} F_{i, t}+\varepsilon_{j, t}$ for managers $\mathrm{j}=1, \ldots 15$.

Based on 156 weekly observations, 4/06/2005-3/26/2008

\begin{tabular}{|c|c|c|c|c|c|c|c|c|c|c|c|c|c|}
\hline & Alpha & T-Stat & $\begin{array}{l}\text { Beta } \\
\text { Carry }\end{array}$ & T-Stat & $\begin{array}{l}\text { Beta } \\
\text { Trend }\end{array}$ & T-Stat & $\begin{array}{l}\text { Beta } \\
\text { Value }\end{array}$ & T-Stat & $\begin{array}{c}\text { Beta } \\
\text { Volatility }\end{array}$ & T-Stat & $\begin{array}{c}\text { R- } \\
\text { Square }\end{array}$ & F-Stat & D-W \\
\hline "Index" & 0.00040 & 1.27 & 0.10 & 2.89 & 0.51 & 9.03 & -0.12 & -3.58 & 0.08 & 0.69 & 0.411 & 26.37 & 2.07 \\
\hline L6 & -0.00057 & -0.50 & 0.55 & 4.23 & 1.07 & 5.15 & -0.04 & -0.35 & -0.10 & -0.22 & 0.271 & 14.09 & 2.16 \\
\hline L10 & -0.00001 & -0.05 & -0.01 & -0.32 & 0.09 & 1.32 & -0.01 & -0.39 & 0.26 & 1.80 & 0.074 & 3.04 & 1.85 \\
\hline L15 & -0.00092 & -0.76 & 0.17 & 1.29 & 0.97 & 4.44 & -0.42 & -3.31 & 0.15 & 0.34 & 0.174 & 7.99 & 2.17 \\
\hline L28 & 0.00116 & $1.85^{\star}$ & -0.00 & -0.07 & 0.09 & 0.87 & -0.08 & -1.26 & 0.38 & 1.57 & 0.057 & 2.31 & 1.80 \\
\hline L29 & 0.00321 & 1.56 & -0.48 & -2.08 & -0.68 & -1.84 & 0.06 & 0.30 & 1.24 & 1.57 & 0.105 & 4.43 & 2.23 \\
\hline L30 & 0.00001 & 0.09 & -0.05 & -0.57 & 0.08 & 0.53 & 0.21 & 2.21 & 0.32 & 0.94 & 0.055 & 2.21 & 2.41 \\
\hline L35 & 0.00026 & 0.21 & 0.07 & 0.54 & 0.21 & 1.00 & -0.08 & -0.65 & -1.00 & -2.15 & 0.059 & 2.37 & 2.29 \\
\hline L42 & 0.00194 & 1.47 & -0.94 & -6.31 & -0.24 & -1.01 & 0.21 & 1.50 & -0.42 & -0.84 & 0.268 & 13.84 & 2.09 \\
\hline L46 & 0.00036 & 0.67 & 0.07 & 1.18 & 0.19 & 2.06 & -0.10 & -1.83 & 0.47 & 2.34 & 0.104 & 4.40 & 1.95 \\
\hline L47 & 0.00036 & 0.89 & -0.15 & -3.37 & 0.03 & 0.45 & -0.31 & -0.73 & -0.05 & -0.32 & 0.134 & 5.88 & 2.25 \\
\hline L49 & 0.00079 & 1.64 & -0.05 & -1.04 & 0.23 & 2.65 & -0.05 & -1.05 & 0.36 & 1.96 & 0.167 & 7.57 & 2.20 \\
\hline L50 & -0.00086 & -0.64 & 0.29 & 1.95 & 1.77 & 7.34 & -0.23 & -1.64 & 1.28 & 2.50 & 0.360 & 21.25 & 1.92 \\
\hline L52 & 0.00080 & 0.68 & 0.67 & 5.08 & 2.05 & 9.65 & -0.35 & -2.86 & -0.47 & -1.05 & 0.464 & 32.75 & 2.45 \\
\hline L53 & 0.00018 & 0.13 & 0.66 & 4.30 & 1.44 & 5.85 & -0.47 & -3.28 & -0.53 & -1.02 & 0.294 & 15.75 & 2.54 \\
\hline L58 & -0.00077 & -1.07 & 0.75 & 9.26 & 0.37 & 2.89 & -0.37 & -4.93 & -0.64 & -2.32 & 0.535 & 43.45 & 2.13 \\
\hline
\end{tabular}

L6, L10 etc. stand for returns the managers, who were live (still on the platform) as of April 2008.

See notes to Table 2 for explanation of factors. 
Table 5: Performance of Individual Currency Managers

\begin{tabular}{|c|c|c|c|c|c|c|c|c|}
\hline Manager & $\begin{array}{l}\text { Average } \\
\text { Excess } \\
\text { Annual } \\
\text { Return }\end{array}$ & Std. Dev. & IR & Rank & $\begin{array}{c}\text { Average } \\
\text { Annual } \\
\text { Alpha }\end{array}$ & $\begin{array}{l}\text { Tracking } \\
\text { Error }\end{array}$ & $\mathrm{IR}^{*}$ & Rank* \\
\hline L6 & $-0.08 \%$ & $11.957 \%$ & -0.01 & 13 & $-3.01 \%$ & $10.20 \%$ & -0.30 & 12 \\
\hline L10 & $0.40 \%$ & $3.532 \%$ & 0.11 & 10 & $-0.11 \%$ & $3.40 \%$ & -0.03 & 11 \\
\hline L15 & $-2.18 \%$ & $11.828 \%$ & -0.18 & 14 & $-4.82 \%$ & $10.75 \%$ & -0.45 & 14 \\
\hline L28 & $6.73 \%$ & $5.732 \%$ & 1.17 & 1 & $6.08 \%$ & $5.56 \%$ & 1.09 & 1 \\
\hline L29 & $16.10 \%$ & $19.282 \%$ & 0.83 & 3 & $16.74 \%$ & $18.24 \%$ & 0.92 & 3 \\
\hline L30 & $1.03 \%$ & $8.123 \%$ & 0.13 & 9 & $0.46 \%$ & $7.90 \%$ & 0.06 & 10 \\
\hline L35 & $0.80 \%$ & $11.084 \%$ & 0.07 & 12 & $1.36 \%$ & $10.75 \%$ & 0.13 & 8 \\
\hline L42 & $8.34 \%$ & $13.654 \%$ & 0.61 & 5 & $10.10 \%$ & $11.68 \%$ & 0.86 & 4 \\
\hline L46 & $2.93 \%$ & $4.972 \%$ & 0.59 & 6 & $1.87 \%$ & $4.71 \%$ & 0.40 & 7 \\
\hline L47 & $1.79 \%$ & $3.844 \%$ & 0.47 & 7 & $1.89 \%$ & $3.58 \%$ & 0.53 & 5 \\
\hline L49 & $5.07 \%$ & $4.693 \%$ & 1.08 & 2 & $4.14 \%$ & $4.28 \%$ & 0.97 & 2 \\
\hline L50 & $1.49 \%$ & $14.800 \%$ & 0.10 & 11 & $-4.49 \%$ & $11.84 \%$ & -0.38 & 13 \\
\hline L52 & $9.16 \%$ & $14.253 \%$ & 0.64 & 4 & $4.21 \%$ & $10.43 \%$ & 0.40 & 6 \\
\hline L53 & $4.34 \%$ & $14.380 \%$ & 0.30 & 8 & $0.97 \%$ & $12.08 \%$ & 0.08 & 9 \\
\hline L58 & $-3.30 \%$ & $9.307 \%$ & -0.35 & 15 & $-4.02 \%$ & $6.35 \%$ & -0.63 & 15 \\
\hline Average & $3.51 \%$ & & 0.37 & & $2.09 \%$ & & 0.24 & \\
\hline
\end{tabular}

$I R=R_{j} / \sigma\left(R_{j}\right)$, where $R_{j}$ is the annualized average excess return and $\sigma\left(R_{j}\right)$ is its annualized standard deviation.

$I R^{*}=\alpha_{j} / \sigma\left(\alpha_{j}\right)$, where $\alpha_{j}$ is the average annual alpha estimated from equation (1) and $\sigma\left(\alpha_{j}\right)$ is its annualized standard deviation, or tracking error. 


\section{Table 6: Regression Results for Individual Currency Managers, April 2005 to March 2006}

Regression Results for $R_{j, t}=\alpha_{j}+\sum_{i} \beta_{i, j} F_{i, t}+\varepsilon_{j, t}$ for managers $\mathrm{j}=1, \ldots 22$.

Based on 52 weekly observations, 4/06/2005-3/29/2006

\begin{tabular}{|c|c|c|c|c|c|c|c|c|c|c|c|c|c|}
\hline & Alpha & T-Stat & $\begin{array}{l}\text { Beta } \\
\text { Carry }\end{array}$ & T-Stat & $\begin{array}{l}\text { Beta } \\
\text { Trend }\end{array}$ & T-Stat & $\begin{array}{l}\text { Beta } \\
\text { Value }\end{array}$ & T-Stat & $\begin{array}{c}\text { Beta } \\
\text { Volatility }\end{array}$ & T-Stat & $\begin{array}{c}\text { R- } \\
\text { Square }\end{array}$ & F-Stat & D-W \\
\hline "Index" & 0.00026 & 0.58 & -0.05 & -0.68 & 0.36 & 4.60 & 0.07 & 1.18 & 0.27 & 0.92 & 0.500 & 11.76 & 2.04 \\
\hline L6 & 0.00019 & 0.08 & 0.54 & 1.45 & 0.83 & 2.14 & 0.15 & 0.46 & 0.54 & 0.37 & 0.269 & 4.34 & 2.44 \\
\hline L10 & 0.00043 & 0.62 & -0.13 & -1.10 & 0.04 & 0.39 & 0.04 & 0.38 & 1.00 & 2.19 & 0.150 & 2.09 & 2.07 \\
\hline L15 & -0.00206 & -0.81 & -0.12 & -0.29 & 0.33 & 0.74 & 0.51 & 1.40 & 1.58 & 0.96 & 0.147 & 2.04 & 2.28 \\
\hline L28 & 0.00104 & 1.11 & 0.03 & 0.21 & 0.13 & 0.84 & -0.09 & -0.69 & -0.69 & -1.14 & 0.036 & 0.45 & 1.11 \\
\hline L29 & 0.00511 & 1.10 & -0.39 & -0.50 & -0.75 & -0.92 & -0.47 & -0.69 & 2.10 & 0.69 & 0.104 & 1.37 & 2.13 \\
\hline L30 & -0.00064 & -0.33 & -0.01 & -0.05 & -0.19 & -0.57 & 0.41 & 1.47 & 0.29 & 0.23 & 0.079 & 1.02 & 2.50 \\
\hline L35 & 0.00092 & 0.78 & 0.21 & 1.09 & 0.22 & 1.09 & -0.40 & -2.35 & 0.13 & 0.17 & 0.117 & 1.56 & 1.45 \\
\hline L42 & 0.00193 & 1.64 & -0.53 & -2.70 & -0.70 & -3.41 & 0.15 & 0.91 & 1.05 & 1.37 & 0.342 & 6.12 & 1.64 \\
\hline L46 & 0.00029 & 0.37 & 0.20 & 1.59 & 0.38 & 2.83 & -0.31 & -2.70 & -0.10 & -0.20 & 0.181 & 2.61 & 2.44 \\
\hline L47 & 0.00001 & 0.05 & -0.14 & -1.04 & 0.26 & 1.84 & -0.22 & -1.86 & 0.33 & 0.62 & 0.250 & 3.93 & 2.44 \\
\hline L49 & 0.00082 & 1.04 & -0.07 & -0.59 & 0.38 & 2.76 & -0.04 & -0.41 & 0.73 & 1.43 & 0.254 & 4.01 & 2.21 \\
\hline L50 & -0.00119 & -0.63 & -0.48 & -1.54 & 1.53 & 4.64 & -0.10 & -0.36 & 2.72 & 2.22 & 0.500 & 11.77 & 1.94 \\
\hline L52 & 0.00101 & 0.53 & 0.38 & 1.21 & 2.06 & 6.26 & 0.43 & 1.57 & -1.30 & -1.06 & 0.661 & 22.92 & 1.99 \\
\hline L53 & 0.00047 & 0.18 & -0.26 & -0.63 & 1.09 & 2.50 & 0.71 & 1.95 & -1.15 & -0.71 & 0.331 & 5.82 & 2.14 \\
\hline L58 & -0.00169 & -1.12 & 0.66 & 2.62 & 0.11 & 0.42 & -0.20 & -0.92 & -1.82 & -1.84 & 0.213 & 3.18 & 1.96 \\
\hline D3 & 0.00001 & 0.01 & -0.24 & -0.79 & -0.69 & -2.11 & 0.24 & 0.90 & -0.28 & -0.23 & 0.106 & 1.40 & 2.03 \\
\hline D5 & -0.00134 & -0.99 & -0.12 & -0.54 & 1.19 & 5.06 & 0.62 & 3.18 & -1.81 & -2.07 & 0.641 & 21.01 & 2.22 \\
\hline D6 & -0.00001 & -0.15 & 0.11 & 1.10 & 0.34 & 3.31 & -0.15 & -1.78 & 0.42 & 1.09 & 0.250 & 3.93 & 1.58 \\
\hline D10 & -0.00164 & -0.55 & -0.18 & -0.36 & 0.30 & 0.58 & 0.43 & 0.99 & -0.63 & -0.33 & 0.061 & 0.77 & 2.84 \\
\hline
\end{tabular}




\begin{tabular}{|c|c|c|c|c|c|c|c|c|c|c|c|c|c|}
\hline D14 & -0.00030 & -0.24 & -0.39 & -1.92 & 0.91 & 4.34 & 0.07 & 0.41 & 0.80 & 1.02 & 0.450 & 9.63 & 2.10 \\
\hline D15 & 0.00143 & 1.04 & -0.11 & -0.50 & 0.23 & 0.98 & -0.17 & -0.89 & 1.67 & 1.87 & 0.157 & 2.19 & 1.54 \\
\hline $\mathrm{D} 21$ & 0.00100 & 1.45 & -0.06 & -0.55 & -0.14 & -1.22 & 0.09 & 0.95 & 0.34 & 0.76 & 0.037 & 0.46 & 1.78 \\
\hline
\end{tabular}

See notes to Table 2 for explanation of factors. 
Table 7: Regression Results for Individual Currency Managers, April 2006 to March 2007

Regression Results for $R_{j, t}=\alpha_{j}+\sum_{i} \beta_{i, j} F_{i, t}+\varepsilon_{j, t}$ for managers $\mathrm{j}=1, \ldots 52$.

Based on 52 weekly observations, 4/05/2006-3/28/2007

\begin{tabular}{|c|c|c|c|c|c|c|c|c|c|c|c|c|c|}
\hline & Alpha & T-Stat & $\begin{array}{l}\text { Beta } \\
\text { Carry }\end{array}$ & T-Stat & $\begin{array}{c}\text { Beta } \\
\text { Trend }\end{array}$ & T-Stat & $\begin{array}{c}\text { Beta } \\
\text { Value }\end{array}$ & T-Stat & $\begin{array}{c}\text { Beta } \\
\text { Volatility }\end{array}$ & T-Stat & $\begin{array}{c}\text { R- } \\
\text { Square }\end{array}$ & F-Stat & D-W \\
\hline "Index" & -0.00017 & -0.53 & 0.14 & 2.62 & 0.35 & 4.96 & -0.12 & -1.88 & 0.39 & 2.79 & 0.613 & 18.63 & 2.45 \\
\hline L1 & -0.00031 & -0.15 & 0.44 & 1.27 & -0.37 & -0.84 & -0.18 & -0.44 & 0.80 & 0.91 & 0.074 & 0.95 & 2.06 \\
\hline $\mathrm{L} 2$ & 0.00043 & 0.41 & 0.11 & 0.60 & 1.11 & 4.79 & 0.93 & 4.40 & -0.98 & -2.13 & 0.691 & 26.33 & 1.74 \\
\hline L3 & -0.00244 & -0.78 & 0.59 & 1.07 & -0.43 & -0.61 & -0.54 & -0.85 & 3.67 & 2.63 & 0.184 & 2.66 & 2.34 \\
\hline L6 & -0.00124 & -0.71 & 0.97 & 3.18 & 1.32 & 3.38 & -0.59 & -1.64 & -1.69 & -2.18 & 0.332 & 5.86 & 2.11 \\
\hline L10 & -0.00048 & -0.76 & 0.10 & 0.95 & 0.13 & 0.97 & -0.09 & -0.72 & 0.36 & 1.29 & 0.128 & 1.74 & 1.79 \\
\hline L12 & -0.00099 & -2.75 & 0.02 & 0.38 & -0.11 & -1.38 & -0.07 & -1.07 & 0.00 & 0.02 & 0.077 & 0.98 & 2.45 \\
\hline L13 & -0.00038 & -0.57 & -0.18 & -1.60 & 0.23 & 1.60 & 0.07 & 0.54 & -0.40 & -1.35 & 0.140 & 1.92 & 1.89 \\
\hline L14 & -0.00076 & -0.37 & 0.69 & 1.92 & 0.98 & 2.13 & -1.00 & -2.40 & 0.57 & 0.63 & 0.281 & 4.61 & 1.97 \\
\hline L15 & -0.00019 & -0.13 & 0.29 & 1.16 & 0.52 & 1.65 & -1.23 & -4.23 & 0.37 & 0.59 & 0.548 & 14.26 & 1.94 \\
\hline L21 & -0.00001 & -0.07 & 0.13 & 0.68 & 0.73 & 2.90 & -0.26 & -1.15 & 0.28 & 0.57 & 0.294 & 4.91 & 1.94 \\
\hline L22 & -0.00026 & -0.45 & -0.16 & -1.63 & 0.08 & 0.65 & 0.19 & 1.64 & 0.09 & 0.36 & 0.078 & 1.00 & 2.32 \\
\hline L23 & 0.00232 & 0.77 & 0.93 & 1.76 & 1.93 & 2.85 & -1.73 & -2.80 & 0.71 & 0.53 & 0.390 & 7.53 & 1.89 \\
\hline L24 & -0.00093 & -1.85 & -0.06 & -0.74 & 0.00 & 0.05 & -0.13 & -1.28 & -0.41 & -1.83 & 0.204 & 3.03 & 1.98 \\
\hline L27 & -0.00072 & -0.38 & 1.12 & 3.32 & 0.45 & 1.06 & -0.43 & -1.11 & 0.82 & 0.97 & 0.297 & 4.98 & 2.28 \\
\hline L28 & 0.00331 & 2.26 & -0.33 & -1.31 & -0.27 & -0.83 & 0.27 & 0.90 & 1.55 & 2.38 & 0.159 & 2.23 & 1.88 \\
\hline L29 & 0.00037 & 0.16 & -1.08 & -2.80 & -0.56 & -1.15 & 0.72 & 1.61 & 1.88 & 1.93 & 0.236 & 3.63 & 2.47 \\
\hline L30 & 0.00028 & 0.18 & -0.28 & -1.06 & 0.28 & 0.82 & 0.28 & 0.91 & -0.07 & -0.11 & 0.043 & 0.53 & 2.27 \\
\hline L32 & 0.00059 & 0.38 & 0.46 & 1.69 & 0.32 & 0.92 & 0.25 & 0.80 & 0.52 & 0.75 & 0.273 & 4.43 & 1.98 \\
\hline L33 & -0.00160 & -0.70 & -0.30 & -0.76 & -0.75 & -1.48 & 0.66 & 1.42 & 1.67 & 1.64 & 0.092 & 1.20 & 1.92 \\
\hline
\end{tabular}




\begin{tabular}{|c|c|c|c|c|c|c|c|c|c|c|c|c|c|}
\hline L34 & -0.00042 & -0.76 & 0.03 & 0.38 & 0.07 & 0.58 & 0.07 & 0.64 & -0.02 & -0.10 & 0.067 & 0.85 & 1.41 \\
\hline L35 & -0.00120 & -0.69 & 0.44 & 1.44 & 1.14 & 2.92 & -0.44 & -1.24 & -1.27 & -1.64 & 0.173 & 2.47 & 2.22 \\
\hline L38 & 0.00078 & 0.62 & 0.11 & 0.49 & 0.43 & 1.54 & -0.10 & -0.39 & 0.28 & 0.50 & 0.101 & 1.32 & 1.84 \\
\hline L41 & -0.00107 & -0.80 & 0.36 & 1.53 & 0.78 & 2.61 & -0.10 & -0.37 & -0.21 & -0.35 & 0.189 & 2.75 & 2.16 \\
\hline L42 & -0.00051 & -0.42 & -0.35 & -1.67 & -0.18 & -0.66 & -0.01 & -0.04 & 1.58 & 2.95 & 0.376 & 7.10 & 1.68 \\
\hline L43 & -0.00060 & -0.77 & 0.01 & 0.13 & 0.07 & 0.45 & -0.15 & -0.96 & 0.53 & 1.54 & 0.192 & 2.81 & 1.47 \\
\hline L45 & 0.00119 & 0.52 & 1.23 & 3.06 & 0.73 & 1.43 & -0.80 & -1.71 & 0.04 & 0.04 & 0.212 & 3.18 & 2.18 \\
\hline L46 & -0.00001 & -0.03 & 0.10 & 0.81 & 0.44 & 2.62 & -0.10 & -0.67 & 0.03 & 0.09 & 0.185 & 2.68 & 1.63 \\
\hline L47 & 0.00135 & 2.20 & 0.22 & 2.05 & -0.15 & -1.12 & -0.42 & -3.40 & 0.02 & 0.08 & 0.248 & 3.89 & 1.67 \\
\hline L49 & 0.00106 & 1.10 & 0.12 & 0.72 & 0.23 & 1.07 & -0.16 & -0.84 & 0.83 & 1.93 & 0.221 & 3.35 & 2.27 \\
\hline L50 & -0.00057 & -0.26 & 0.35 & 0.93 & 2.37 & 4.90 & -0.45 & -1.03 & 1.04 & 1.09 & 0.508 & 12.13 & 2.34 \\
\hline L51 & 0.00045 & 0.31 & -0.06 & -0.25 & 0.00 & 0.02 & -0.33 & -1.14 & -0.61 & -0.96 & 0.106 & 1.40 & 2.09 \\
\hline L52 & -0.00216 & -1.17 & 0.35 & 1.08 & 1.53 & 3.70 & 0.05 & 0.15 & 1.11 & 1.35 & 0.378 & 7.16 & 2.68 \\
\hline L53 & -0.00110 & -0.51 & 0.23 & 0.62 & 0.15 & 0.32 & -0.28 & -0.64 & 1.02 & 1.07 & 0.069 & 0.88 & 2.56 \\
\hline L54 & -0.00020 & -0.33 & 0.16 & 1.44 & 0.41 & 2.93 & -0.12 & -0.99 & 0.04 & 0.14 & 0.230 & 3.52 & 1.93 \\
\hline L55 & 0.00054 & 0.25 & 0.64 & 1.68 & 0.16 & 0.34 & 0.72 & 1.61 & -0.66 & -0.68 & 0.451 & 9.66 & 2.11 \\
\hline L56 & -0.00028 & -0.20 & 0.12 & 0.49 & 1.82 & 5.81 & -0.24 & -0.83 & 1.80 & 2.91 & 0.674 & 24.34 & 1.76 \\
\hline L58 & -0.00030 & -0.38 & 0.34 & 2.46 & 0.67 & 3.78 & -0.01 & -0.10 & -0.31 & -0.89 & 0.381 & 7.25 & 2.65 \\
\hline D1 & -0.00126 & -2.35 & -0.05 & -0.59 & 0.02 & 0.22 & -0.06 & -0.55 & 0.11 & 0.50 & 0.117 & 1.57 & 2.35 \\
\hline D2 & -0.00181 & -1.08 & -1.00 & -3.40 & -0.19 & -0.51 & 0.66 & 1.93 & 1.27 & 1.70 & 0.293 & 4.87 & 2.27 \\
\hline D3 & 0.00364 & 1.34 & 0.13 & 0.27 & -0.97 & -1.59 & -0.06 & -0.10 & 0.43 & 0.35 & 0.064 & 0.82 & 2.38 \\
\hline D4 & -0.00001 & -0.55 & -0.01 & -0.46 & -0.02 & -0.66 & 0.03 & 1.09 & 0.13 & 1.91 & 0.082 & 1.05 & 1.90 \\
\hline D5 & -0.00240 & -1.55 & 0.45 & 1.68 & 1.36 & 3.93 & -0.05 & -0.17 & 0.03 & 0.05 & 0.339 & 6.04 & 1.81 \\
\hline D6 & 0.00034 & 0.46 & -0.17 & -1.33 & 0.39 & 2.39 & 0.10 & 0.67 & 0.19 & 0.61 & 0.253 & 3.99 & 2.05 \\
\hline D7 & -0.00152 & -0.73 & -0.31 & -0.87 & -0.00 & -0.01 & -0.04 & -0.10 & -0.03 & -0.03 & 0.062 & 0.79 & 2.14 \\
\hline D11 & -0.00160 & -0.83 & 0.18 & 0.54 & -0.47 & -1.09 & -0.45 & -1.15 & 0.39 & 0.45 & 0.065 & 0.83 & 2.44 \\
\hline D12 & 0.00161 & 1.17 & 0.12 & 0.52 & 0.14 & 0.47 & -0.18 & -0.63 & 0.71 & 1.16 & 0.087 & 1.13 & 2.14 \\
\hline D14 & -0.00040 & -0.40 & 0.00 & 0.03 & 1.10 & 4.80 & 0.00 & 0.01 & -0.13 & -0.29 & 0.396 & 7.73 & 1.80 \\
\hline D15 & -0.00028 & -0.27 & -0.13 & -0.73 & 0.52 & 2.23 & 0.04 & 0.19 & 0.75 & 1.63 & 0.312 & 5.34 & 1.80 \\
\hline
\end{tabular}




\begin{tabular}{|c|c|c|c|c|c|c|c|c|c|c|c|c|c|}
\hline D17 & -0.0001 & -0.21 & 0.06 & 0.85 & -0.10 & -1.08 & -0.05 & -0.61 & 0.61 & 3.25 & 0.227 & 3.47 & 2.33 \\
\hline D19 & 0.00054 & 0.36 & 0.08 & 0.32 & -0.23 & -0.69 & -0.04 & -0.15 & 0.65 & 0.99 & 0.025 & 0.31 & 2.36 \\
\hline D20 & -0.00038 & -0.51 & 0.27 & 2.12 & 0.52 & 3.15 & -0.22 & -1.49 & 0.63 & 1.94 & 0.414 & 8.32 & 1.76 \\
\hline D21 & 0.00109 & 1.33 & 0.18 & 1.29 & 0.18 & 1.00 & -0.29 & -1.74 & -0.11 & -0.32 & 0.089 & 1.16 & 2.03 \\
\hline
\end{tabular}

See notes to Table 2 for explanation of factors. 
Table 8: Regression Results for Individual Currency Managers, April 2007 to March 2008

Regression Results for $R_{j, t}=\alpha_{j}+\sum_{i} \beta_{i, j} F_{i, t}+\varepsilon_{j, t}$ for managers $\mathrm{j}=1, \ldots 46$.

Based on 52 weekly observations, 4/04/2007-3/26/2008

\begin{tabular}{|c|c|c|c|c|c|c|c|c|c|c|c|c|c|}
\hline & Alpha & T-Stat & $\begin{array}{l}\text { Beta } \\
\text { Carry }\end{array}$ & T-Stat & $\begin{array}{c}\text { Beta } \\
\text { Trend }\end{array}$ & T-Stat & $\begin{array}{c}\text { Beta } \\
\text { Value }\end{array}$ & T-Stat & $\begin{array}{c}\text { Beta } \\
\text { Volatility }\end{array}$ & T-Stat & $\begin{array}{c}\text { R- } \\
\text { Square }\end{array}$ & F-Stat & D-W \\
\hline "Index" & 0.00047 & 1.17 & 0.22 & 6.15 & 0.37 & 4.76 & -0.12 & -3.51 & 0.15 & 1.17 & 0.673 & 24.27 & 2.20 \\
\hline L1 & -0.00186 & -0.96 & 0.06 & 0.39 & 0.20 & 0.53 & 0.02 & 0.17 & 0.46 & 0.73 & 0.036 & 0.44 & 1.74 \\
\hline L2 & 0.00001 & 0.01 & 0.80 & 3.16 & 0.99 & 1.82 & 0.34 & 1.43 & 0.55 & 0.61 & 0.339 & 6.04 & 1.77 \\
\hline L3 & 0.00042 & 0.12 & 0.57 & 1.82 & 0.73 & 1.08 & -0.42 & -1.38 & 2.44 & 2.15 & 0.185 & 2.67 & 2.18 \\
\hline L6 & -0.00205 & -0.93 & 0.57 & 2.84 & 1.19 & 2.78 & -0.18 & -0.96 & 0.30 & 0.42 & 0.329 & 5.77 & 1.92 \\
\hline L8 & -0.00008 & -0.34 & 1.41 & 6.45 & 0.96 & 2.06 & -1.05 & -5.04 & 0.82 & 1.04 & 0.672 & 24.14 & 2.63 \\
\hline L9 & 0.00026 & 0.20 & 1.05 & 8.75 & 0.62 & 2.45 & -0.33 & -2.94 & -0.31 & -0.73 & 0.813 & 51.20 & 1.99 \\
\hline L10 & 0.00019 & 0.27 & -0.06 & -0.93 & 0.06 & 0.44 & 0.00 & 0.04 & 0.04 & 0.19 & 0.069 & 0.88 & 1.70 \\
\hline L12 & -0.00021 & -0.28 & -0.02 & -0.29 & -0.07 & -0.53 & 0.03 & 0.52 & -0.26 & -1.05 & 0.068 & 0.86 & 1.68 \\
\hline L13 & -0.00001 & -0.03 & -0.06 & -1.06 & -0.04 & -0.31 & -0.05 & -0.95 & 0.08 & 0.37 & 0.107 & 1.41 & 1.80 \\
\hline L14 & 0.00236 & 1.22 & 0.04 & 0.28 & 0.69 & 1.85 & -0.40 & -2.37 & -0.11 & -0.18 & 0.206 & 3.06 & 1.91 \\
\hline L15 & -0.00035 & -0.17 & 0.19 & 1.02 & 1.02 & 2.55 & -0.48 & -2.69 & -0.15 & -0.23 & 0.293 & 4.89 & 1.97 \\
\hline L17 & 0.00112 & 0.73 & 0.32 & 2.32 & -0.18 & -0.60 & -0.30 & -2.23 & 0.52 & 1.04 & 0.172 & 2.45 & 2.17 \\
\hline L19 & -0.00083 & -0.83 & -0.18 & -1.98 & 0.38 & 1.95 & -0.08 & -0.98 & -0.73 & -2.23 & 0.194 & 2.84 & 2.02 \\
\hline $\mathrm{L} 20$ & 0.00199 & 1.32 & 0.30 & 2.20 & 0.90 & 3.06 & 0.02 & 0.18 & 0.08 & 0.17 & 0.290 & 4.81 & 2.11 \\
\hline L21 & 0.00040 & 0.21 & 0.09 & 0.52 & 0.01 & 0.04 & -0.40 & -2.45 & -0.42 & -0.67 & 0.186 & 2.70 & 1.74 \\
\hline L22 & 0.00022 & 0.20 & -0.20 & -2.06 & -0.13 & -0.62 & 0.02 & 0.31 & -0.09 & -0.25 & 0.150 & 2.08 & 2.37 \\
\hline L23 & 0.00647 & 1.93 & 0.24 & 0.80 & -0.08 & -0.13 & -0.59 & -2.03 & -1.43 & -1.30 & 0.255 & 4.04 & 2.28 \\
\hline L24 & -0.00018 & -0.15 & -0.08 & -0.72 & 0.28 & 1.20 & 0.10 & 1.02 & -0.11 & -0.29 & 0.061 & 0.76 & 1.97 \\
\hline L25 & -0.00001 & -0.04 & -0.15 & -1.19 & 0.41 & 1.53 & 0.03 & 0.26 & 0.57 & 1.25 & 0.306 & 5.19 & 1.55 \\
\hline
\end{tabular}




\begin{tabular}{|c|c|c|c|c|c|c|c|c|c|c|c|c|c|}
\hline L27 & -0.00004 & -0.25 & 0.91 & 5.60 & 0.77 & 2.22 & -0.29 & -1.91 & -0.11 & -0.19 & 0.628 & 19.86 & 2.14 \\
\hline L28 & -0.00059 & -0.82 & 0.02 & 0.33 & 0.25 & 1.80 & -0.08 & -1.37 & 0.33 & 1.43 & 0.230 & 3.53 & 2.20 \\
\hline L29 & 0.00590 & 1.56 & -0.46 & -1.34 & -0.01 & -0.01 & 0.58 & 1.75 & 0.45 & 0.36 & 0.169 & 2.40 & 2.14 \\
\hline L30 & 0.00032 & 0.25 & 0.00 & 0.06 & 0.08 & 0.32 & 0.15 & 1.35 & 0.52 & 1.25 & 0.142 & 1.96 & 1.94 \\
\hline L32 & -0.00026 & -0.11 & 1.12 & 5.53 & 1.06 & 2.46 & -0.14 & -0.76 & -0.26 & -0.35 & 0.627 & 19.79 & 2.38 \\
\hline L33 & 0.00107 & 0.50 & -0.68 & -3.53 & -0.01 & -0.03 & 0.32 & 1.71 & 0.96 & 1.37 & 0.542 & 13.92 & 1.91 \\
\hline L34 & 0.00159 & 0.54 & 0.85 & 3.24 & -0.10 & -0.19 & -0.56 & -2.22 & 2.13 & 2.24 & 0.211 & 3.16 & 1.36 \\
\hline L35 & 0.00251 & 0.81 & -0.09 & -0.33 & -0.07 & -0.12 & 0.23 & 0.87 & -1.77 & -1.74 & 0.132 & 1.79 & 2.37 \\
\hline L36 & -0.00117 & -1.33 & -0.11 & -1.47 & -0.07 & -0.44 & -0.06 & -0.89 & 0.23 & 0.81 & 0.203 & 3.00 & 2.78 \\
\hline L38 & 0.00070 & 0.40 & -0.12 & -0.78 & 0.64 & 1.88 & -0.09 & -0.59 & 0.27 & 0.47 & 0.193 & 2.82 & 2.19 \\
\hline L39 & -0.00374 & -1.43 & 0.05 & 0.21 & -0.53 & -1.04 & 0.80 & 3.50 & 0.11 & 0.13 & 0.274 & 4.45 & 1.90 \\
\hline L41 & 0.00039 & 0.33 & 0.46 & 4.27 & 0.52 & 2.28 & -0.03 & -0.29 & -0.10 & -0.27 & 0.505 & 12.01 & 2.24 \\
\hline L42 & 0.00683 & 2.00 & -1.77 & -5.69 & 0.57 & 0.86 & 0.55 & 1.85 & -3.65 & -3.27 & 0.426 & 8.72 & 2.03 \\
\hline L43 & -0.00077 & -0.85 & 0.00 & 0.03 & 0.13 & 0.76 & -0.20 & -2.57 & -0.32 & -1.10 & 0.215 & 3.23 & 2.11 \\
\hline L44 & -0.00530 & -2.01 & 0.22 & 0.92 & -0.63 & -1.24 & -0.11 & -0.51 & 1.76 & 2.03 & 0.097 & 1.27 & 1.52 \\
\hline L45 & 0.00012 & 0.07 & 1.08 & 7.55 & 0.36 & 1.18 & -0.45 & -3.33 & 0.56 & 1.09 & 0.702 & 27.69 & 2.42 \\
\hline L46 & 0.00070 & 0.55 & 0.10 & 0.92 & -0.01 & -0.07 & -0.10 & -0.92 & 0.77 & 1.85 & 0.097 & 1.27 & 1.84 \\
\hline L47 & 0.00011 & 0.22 & -0.23 & -5.03 & 0.11 & 1.10 & 0.09 & 2.19 & -0.35 & -2.07 & 0.420 & 8.52 & 2.69 \\
\hline L49 & 0.00103 & 1.35 & -0.15 & -2.16 & -0.09 & -0.60 & -0.08 & -1.22 & 0.11 & 0.46 & 0.268 & 4.31 & 2.00 \\
\hline L50 & -0.00035 & -0.12 & 0.54 & 2.08 & 1.67 & 2.98 & 0.10 & 0.42 & 1.47 & 1.56 & 0.303 & 5.13 & 1.79 \\
\hline L51 & -0.00097 & -0.95 & 0.19 & 2.05 & 0.32 & 1.62 & -0.00 & -0.04 & 0.77 & 2.32 & 0.237 & 3.66 & 2.17 \\
\hline L52 & 0.00351 & 1.76 & 0.67 & 3.68 & 1.08 & 2.80 & -0.88 & -5.09 & -0.26 & -0.40 & 0.597 & 17.43 & 2.18 \\
\hline L53 & 0.00001 & 0.00 & 0.95 & 4.81 & 1.34 & 3.17 & -0.89 & -4.73 & 0.17 & 0.24 & 0.624 & 19.55 & 2.38 \\
\hline L54 & 0.00097 & 1.58 & 0.33 & 6.04 & 0.50 & 4.25 & -0.18 & -3.45 & 0.08 & 0.43 & 0.677 & 24.68 & 2.42 \\
\hline L55 & 0.00258 & 1.55 & 0.49 & 3.26 & 0.03 & 0.12 & 0.13 & 0.95 & 0.11 & 0.20 & 0.351 & 6.38 & 1.87 \\
\hline L56 & 0.00044 & 0.24 & 0.29 & 1.77 & 1.11 & 3.11 & -0.40 & -2.54 & 1.31 & 2.19 & 0.406 & 8.03 & 1.54 \\
\hline L58 & -0.00043 & -0.32 & 0.86 & 7.04 & 0.30 & 1.16 & -0.37 & -3.20 & -0.41 & -0.93 & 0.758 & 36.86 & 1.92 \\
\hline
\end{tabular}

See notes to Table 2 for explanation of factors. 
Table 9: Fraction of Managers with Significant Betas

\begin{tabular}{|l|c|c|c|c|}
\hline & Carry Beta & Trend Beta & Value Beta & $\begin{array}{l}\text { Volatility } \\
\text { Beta }\end{array}$ \\
\hline $\begin{array}{l}\text { April 05 - } \\
\text { March 06 }\end{array}$ & $9 \%$ & $50 \%$ & $14 \%$ & $14 \%$ \\
\hline $\begin{array}{l}\text { April 06 - } \\
\text { March 07 }\end{array}$ & $15 \%$ & $35 \%$ & $10 \%$ & $13 \%$ \\
\hline $\begin{array}{l}\text { April 07 - } \\
\text { March 08 }\end{array}$ & $50 \%$ & $28 \%$ & $37 \%$ & $17 \%$ \\
\hline
\end{tabular}

\section{Table 10: Alpha Regressions}

This exhibit presents the results of cross-sectional regressions of:

$\alpha_{j t}=\delta_{0}+\delta_{1} \alpha_{j t-1}+\mu_{j t}$.

\begin{tabular}{|l|c|c|c|c|c|c|}
\hline & $\begin{array}{c}\text { Number of } \\
\text { Funds }\end{array}$ & Intercept & T-Stat & $\begin{array}{l}\text { Coefficient, } \\
\text { Alpha } \\
\text { Year t-1 }\end{array}$ & T-Stat & R-Square \\
\hline $\begin{array}{l}\text { April 06- } \\
\text { March 07 }\end{array}$ & 21 & -0.00001 & -0.01 & 0.11 & 0.53 & 0.015 \\
\hline $\begin{array}{l}\text { April 07 - } \\
\text { March 08 }\end{array}$ & 37 & 0.00085 & $\mathbf{2 . 5 3}$ & 0.16 & 0.53 & 0.008 \\
\hline
\end{tabular}




\section{Table 11: Beta Regressions}

This exhibit presents the results of cross-sectional regressions of: $\beta_{j t}^{k}=\lambda_{0}+\lambda_{t-1} \beta_{j t}^{k}+\varepsilon_{i t}$, for $\mathrm{k}=1, \ldots 4$ (carry, trend, value, volatility).

\begin{tabular}{|l|c|c|c|c|c|c|}
\hline $\begin{array}{l}\text { Panel A. } \\
\text { Carry }\end{array}$ & $\begin{array}{c}\text { Number of } \\
\text { Funds }\end{array}$ & Intercept & T-Stat & $\begin{array}{l}\text { Coefficient, } \\
\text { Beta Carry } \\
\text { Year t-1 }\end{array}$ & T-Stat & R-Square \\
\hline $\begin{array}{l}\text { April 06- } \\
\text { March 07 }\end{array}$ & 21 & 0.13 & 1.66 & 0.68 & $\mathbf{2 . 7 0}$ & 0.278 \\
\hline $\begin{array}{l}\text { April 07 - } \\
\text { March 08 }\end{array}$ & 37 & 0.04 & 0.54 & 0.74 & $\mathbf{4 . 5 0}$ & 0.369 \\
\hline
\end{tabular}

\begin{tabular}{|l|c|c|c|c|c|c|}
\hline $\begin{array}{l}\text { Panel B } \\
\text { Trend }\end{array}$ & $\begin{array}{c}\text { Number of } \\
\text { Funds }\end{array}$ & Intercept & T-Stat & $\begin{array}{l}\text { Coefficient, } \\
\text { Beta Trend } \\
\text { Year t-1 }\end{array}$ & T-Stat & R-Square \\
\hline $\begin{array}{l}\text { April 06- } \\
\text { March 07 }\end{array}$ & 21 & 0.17 & 1.50 & 0.88 & $\mathbf{6 . 1 2}$ & 0.663 \\
\hline $\begin{array}{l}\text { April 07 - } \\
\text { March 08 }\end{array}$ & 37 & 0.26 & 3.16 & 0.34 & $\mathbf{3 . 4 0}$ & 0.248 \\
\hline
\end{tabular}

\begin{tabular}{|l|c|c|c|c|c|c|}
\hline $\begin{array}{l}\text { Panel C } \\
\text { Value }\end{array}$ & $\begin{array}{c}\text { Number of } \\
\text { Funds }\end{array}$ & Intercept & T-Stat & $\begin{array}{l}\text { Coefficient, } \\
\text { Beta Value } \\
\text { Year t-1 }\end{array}$ & T-Stat & R-Square \\
\hline $\begin{array}{l}\text { April 06 - } \\
\text { March 07 }\end{array}$ & 21 & -0.10 & -1.22 & -0.26 & -1.01 & 0.051 \\
\hline $\begin{array}{l}\text { April 07 - } \\
\text { March 08 }\end{array}$ & 37 & -0.07 & -1.41 & 0.34 & $\mathbf{3 . 7 5}$ & 0.287 \\
\hline
\end{tabular}

\begin{tabular}{|l|c|c|c|c|c|c|}
\hline $\begin{array}{l}\text { Panel D } \\
\text { Volatility }\end{array}$ & $\begin{array}{c}\text { Number of } \\
\text { Funds }\end{array}$ & Intercept & T-Stat & $\begin{array}{l}\text { Coefficient, } \\
\text { Beta Vol. } \\
\text { Year t-1 }\end{array}$ & T-Stat & R-Square \\
\hline $\begin{array}{l}\text { April 06 - } \\
\text { March 07 }\end{array}$ & 21 & 0.32 & 1.64 & 0.15 & 0.95 & 0.045 \\
\hline $\begin{array}{l}\text { April 07 - } \\
\text { March 08 }\end{array}$ & 37 & 0.02 & 0.11 & 0.22 & 1.32 & 0.047 \\
\hline
\end{tabular}

